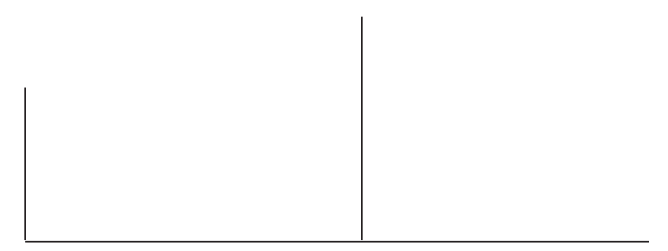

Rev. Latinoam. Psicopat. Fund., III, 1, 84-116

\title{
O desejo na Grécia Clássica
}

\author{
Zeferino Rocha
}

O presente trabalho é a segunda parte de uma pesquisa que estou fazendo sobre "O Desejo na Grécia Antiga" e tem como objetivo apresentar as primeiras sistematizações teóricas que os filósofos da Grécia Clássica, particularmente Sócrates, Platão e Aristóteles, deram às manifestações do desejo, elaboradas pelos poetas épicos, líricos e trágicos e pelos filósofos da Grécia Arcaica. Demos especial destaque ao "Éros" socrático e ao que Platão diz sobre "Éros" no Banquete e no Fedro. E, finalmente, tentamos resumir o essencial da doutrina de Aristóteles sobre os fundamentos de uma metafísica do desejo.

Palavras-chave: Desejo, dialética, Eros, psique, metafísica do desejo 


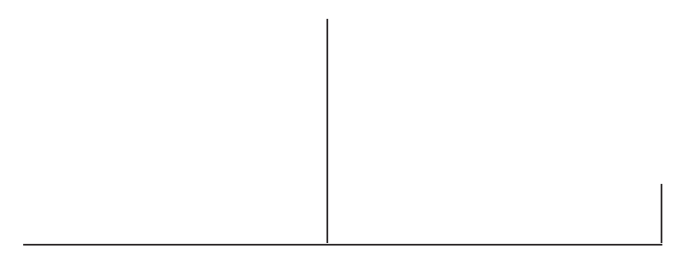

Introdução

Dando continuidade a um trabalho anterior, no qual analisamos as primeiras manifestações do desejo na Grécia Arcaica $^{1}$, é meu propósito, no presente artigo, mostrar de que modo aquelas primeiras manifestações do desejo receberam uma sistematização teórica no período clássico do pensamento helênico, vale dizer, nas filosofias de Sócrates, Platão e Aristóteles.

Há dois fenômenos, um de ordem política e outro de ordem filosófica, que nos ajudam a compreender por que o trabalho de conceituação teórica do desejo pôde ser feito na Grécia Clássica. Quando floresceu o período clássico da cultura helênica, grandes eram as perspectivas de prosperidade que se abriam, para Atenas, no cenário sociocultural e político da Hélade. Sob o comando de Péricles, Atenas conseguiu, no século $\mathrm{V}$ a.C., uma hegemonia política, cultural e militar sobre todo o povo grego.

No campo filosófico, que mais diretamente aqui nos interessa, houve também, nesse período, uma profunda mudança de perspectiva

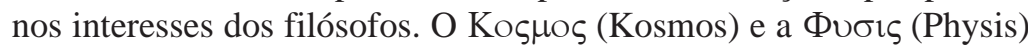
deixaram de ser o centro do filosofar e cederam seu lugar ao estudo do Homem. Teve início, então, o que se chamou de "modernidade grega". Em perspectivas parecidas, mas essencialmente divergentes, Sócrates e os Sofistas tornaram-se os artífices desta "modernidade"2, à medida que questionaram - cada um a seu modo -, o $\varepsilon \theta 0 \varsigma$ (ethos) tradicional e a visão de mundo (Weltanschauung) da Grécia Arcaica, vale dizer, o modo como os deuses, o mundo e a alma humana eram, então, concebidos e se tornaram objeto de estudo e de reflexão filosófica.

1. Cf. Zeferino Rocha, "O desejo na Grécia Arcaica”, in Revista Latinoamericana de Psicopatologia Fundamental. Vol.II, no 4/1999, pp. 94-122.

2. Este tema da "modernidade grega" foi abordado por Henrique de Lima Vaz no seu belo artigo "Sentido e não-sentido na Crise da Modernidade" (1994), p. 6. Dele também tratei no meu trabalho: "A questão da diferença e do sujeito no horizonte filosófico da crítica da Racionalidade Moderna” (1994), pp. 450-452. 


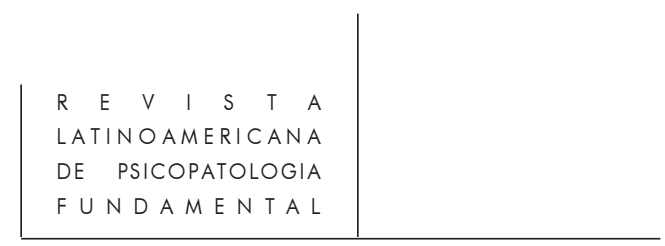

Nas origens do período clássico, a crise da "modernidade grega" lançou a Sócrates e, depois, sobretudo, a Platão o grande desafio de repensar os fundamentos de uma nova ciência do ethos, pois a antiga se via ameaçada pela oposição que os

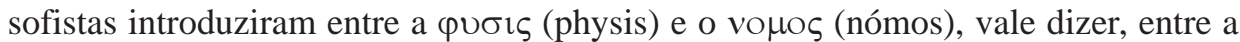
natureza e a lei. Fazia também parte do desafio, encontrar uma nova explicação racional para o Mundo, uma vez que a filosofia pré-socrática estava abalada por causa da oscilação entre o "imobilismo metafísico" de Parmênides e o perpétuo "devir" - $\pi \alpha \nu \tau \alpha \rho \varepsilon i$ (tudo flui) de Heráclito de Éfeso. Repensados deviam ser os fundamentos do próprio conceito de ciência, pois esta também estava ameaçada pelo relativismo de Protágoras.

\section{O desejo no discurso e na dialética dos sofistas}

Não vou me deter na análise do que disseram os sofistas sobre o desejo. Lembrarei apenas que, no contexto sociocultural do século $\mathrm{V}$ a.C., eram chamados de "sofistas" todos aqueles que tinham, como profissão, a arte ou a técnica de ensinar aos outros o segredo do êxito, através da astúcia e dos recursos especiais que ofereciam a eloqüência e a retórica. A linguagem era olhada como uma arte que a tudo podia ser aplicada. Assim compreendida, a sofística floresceu por causa do clima cético e dos impasses a que chegou a filosofia pré-socrática.

Os filósofos anteriores insistiam na insegurança do conhecimento sensível e esta dúvida terminou atingindo a própria razão, ou seja, a capacidade de o homem conhecer a verdade objetiva. Daí resultou um ceticismo gnosiológico que se tornou uma das características fundamentais da doutrina de Protágoras e de Górgias, seguramente os mais conhecidos entre os sofistas desse período. A máxima paradigmática do relativismo cético era a frase de Protágoras: "O homem é a mediada de todas as coisas; das que são para que sejam, e das que não são, para que não sejam".

\section{A arte erística}

Num clima geral de ceticismo, nada mais oportuno, para os sofistas, do que a arte erística, vale dizer, a arte da disputa e da retórica. O seu objetivo não era procurar a verdade, mas refutar os adversários. ${ }^{3}$ Ora, todo discurso que visa a persuasão tem que lidar não só com a magia das palavras ou com a argúcia da inteligência, mas, sobretudo, com a arte de tocar o coração e os sentimentos dos ouvintes. Por

3. Sobre os sofistas e o lugar que eles ocuparam na Grécia do século V, permito-me enviar o leitor ao que escrevi no meu livro A morte de Sócrates. Uma mensagem ética para nosso tempo (1994), pp. 150-170/196-200. 


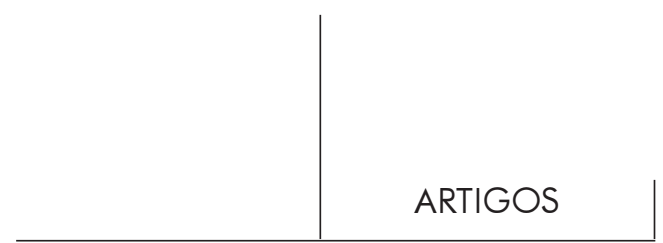

isso, pode-se dizer que o "coração" e suas "razões", bem como os desejos e os sentimentos estão no centro da análise filosófica do homem feita pelos sofistas.

Como lembra Jean Frère, todos os atributos, dados pelos sofistas ao discurso, demonstram que sua arte dialética era movida muito mais pelas potências afetivas e irracionais da alma do que pela força demonstrativa da razão. Para eles, o discurso era tirano e capaz de seduzir os ouvintes, despojando-lhes de suas próprias convicções e pontos de vista. O discurso sofista, portanto, era um discurso no qual o outro era apenas um objeto de manipulação e não um sujeito com o qual se queria verdadeiramente dialogar.

\section{O desejo do herói}

No elogio que Górgias faz do herói, um lugar de destaque foi dado ao desejo. O herói é guiado não só pela força intelectual, mas também pelo vigor dos sentimentos e do afeto $(\rho \omega \mu \eta)$. Além de lutador, ele é um "apaixonado" e um "amigo das coisas belas" ( $\varphi \imath \lambda \alpha \kappa o v)$. Quando dominado pelo "desejo ardente", imposto seja pela divindade ou por um outro mais forte, o homem nada pode fazer e não é mais responsável pelos seus atos.

Esse domínio que a "paixão" exerce sobre o outro pode também ser conseguido pelo discurso. O discurso encanta e enfeitiça e pode fazer passar, por justo, o que é injusto, pode também despojar o ouvinte de seu "vigor" intelectual e fazer dele um irresponsável. É verdade que essa força do discurso também se efetiva nas coisas boas. O discurso poético e trágico pode tocar os sentimentos mais nobres daqueles que o ouvem. O discurso é, então, comparado às drogas, que têm poder sobre o corpo e sobre a alma, e que tanto podem acalmar a dor quanto tirar a vida daquele que sofre. O remédio, quando usado indevidamente, torna-se veneno.

Os sofistas também não deixaram de ressaltar os perigos do amor. Éros é comparado às armadilhas e redes usadas, pelos caçadores e pescadores, para capturar suas presas. Uma vez apanhado na armadilha do amor-paixão, que é uma forma ilegítima de amor, o homem já não mais reflete nem delibera. Dele nascem os "sofrimentos vãos", as "terríveis doenças" e os "delírios incuráveis". A esta força do amor tirano, os sofistas opuseram o vigor $(\rho \omega \mu \eta)$ do desejo autêntico ( $\pi$ oӨo $)$ ). Pródicos diz que o Vício $(\mathrm{K} \alpha \kappa \imath \alpha)$, que se deleita nos prazeres fáceis, ignora o esforço ( $\pi$ ovos) que é o segredo do verdadeiro desejo, pois "sem esforço nem sofrimento, os deuses não concedem coisas belas e boas aos homens". ${ }^{4}$

4. Citado por Jean Frère no seu livro Lês grecs et le désir de l’être (1981), p. 94, no 95. Sobre o lugar do desejo na dialética sofística ver o capítulo "Le discours du désir: les sophistes". Idem, Ibidem, pp. 85-96. 


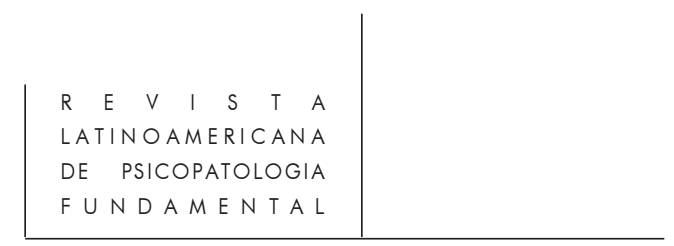

Mas deixemos os sofistas e, para falar sobre o desejo, demos a palavra aos três grandes mestres que levaram a filosofia grega ao apogeu. Eles muito têm a nos dizer. Comecemos por Sócrates.

\section{O desejo na vida e na missão de Sócrates}

Inegavelmente, o desejo, sob a denominação de Eros, tem um lugar de destaque na doutrina de Sócrates e, mais do que na doutrina, na missão que deu sentido à sua vida. Esta missão, como ele próprio disse, lhe foi confiada pelo deus Apolo, e Platão a definiu como uma "terapia da alma".

\section{A terapia da alma}

Cuidando da alma, Sócrates identificou sua vida com a missão de tornar virtuosos os concidadãos atenienses que encontrava em seu caminho. Para ele, o importante não era viver, mas viver virtuosamente, ou seja, viver conhecendo e assumindo as razões do viver. Virtuoso, para os gregos, era todo aquele que adquiria excelência naquilo que fazia, tornando a vida uma tarefa digna de ser vivida. Cuidando da alma, Sócrates queria que seus concidadãos fizessem de suas vidas uma existência

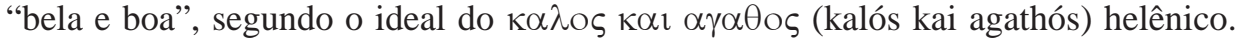
Como diria Michel Foucault, o propósito ético-poético de Sócrates era fazer do ethos dos indivíduos uma verdadeira obra de arte. "Mas não poderia a vida de todos transformar-se numa obra de arte? Por que o abajour ou a casa hão de ser objetos de arte, mas não a vida?" ${ }^{6}$

Sócrates retomou, num contexto filosoficamente mais rico e elaborado, o $\theta u \mu \circ$ (thymós) homérico, em virtude do qual o herói preferia morrer a viver na desonra.

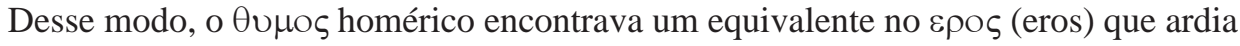
no coração do homem Sócrates, fazendo dele um filósofo, ou seja, um amigo da sabedoria, o qual igualmente preferia morrer a deixar de filosofar, uma vez que esta era a missão que o deus lhe confiara.

Diante do Tribunal de Atenas que o condenou à morte, Sócrates, depois de citar os exemplos de alguns heróis que preferiram morrer a viver na desonra, diz:

Ó atenienses, correndo o risco de ser morto, eu permaneci no meu posto em

Potidéa, Amfipolis e em Délion, quando os chefes, escolhidos por vós para a missão de chefes, me designaram um lugar nos combates. Agora, quando é o deus que

5. Platão. Laques, 186 d-e.

6. Citado por John Rajchman. Eros e verdade. Lacan, Foucault e a questão ética (1993), p. 115. 


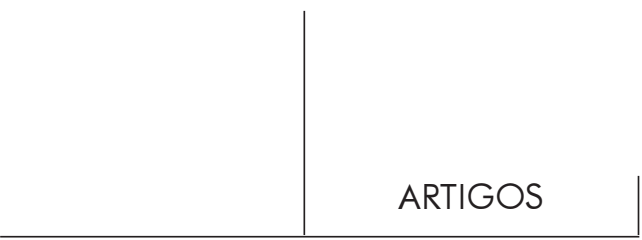

determina meu lugar (pois tal é minha convicção) com a obrigação de viver filosofando e interrogando a mim mesmo e aos outros, eu me conduziria de modo estranho, se desertasse deste lugar por causa do medo da morte ou de qualquer outra coisa.

O filósofo, como o herói, abraça com "zelo ardente" a causa que lhe foi confiada e para cumpri-la, se necessário, está pronto a enfrentar todos os riscos, inclusive o da morte. Por isso, Sócrates conclui: "Ó atenienses, eu vos sou grato e vos amo, mas obedecerei ao deus antes que a vós, e enquanto tiver alento e enquanto for capaz, não espereis que deixe de filosofar" '

Na aceitação desta missão há mais do que uma simples adesão intelectual a uma profissão, nela prevalecem o ideal e o amor de uma causa, alimentados pela força de um coração valente. A missão de Sócrates era a razão de ser de sua vida, pois não são as idéias nem os conceitos que sustentam o amor pela vida, mas os ideais, ou, dito de outro modo, ninguém morre por causa das idéias, morre-se por causa dos ideais, sem os quais a vida perde seu sentido.

Por esta razão, Sócrates colocou o ideal ético no centro de sua vida e de sua filosofia e consagrou-as ao cuidado da alma. Seu trabalho era dirigido para um fim último transcendente, no qual se encontrava, para os gregos, o segredo da eudaimonia, ou seja, da felicidade última do homem. É muito provável, porém, que este fim último transcendente seja uma idéia mais de Platão do que de Sócrates, pois este queria fazer o homem virtuoso, não para que ele conseguisse, como pensavam os órficos, os pitagóricos e o próprio Platão, a felicidade numa outra vida. Para Sócrates, o homem virtuoso é feliz e encontra sua felicidade, quando, já nesta vida, vive bem e em harmonia consigo mesmo. ${ }^{8}$

\section{A maiêutica socrática}

A arte da maiêutica ${ }^{9}$ define o método e a maneira de filosofar de Sócrates e é dinamizada pelo desejo apaixonado da verdade e pelo amor do divino. Se, no exercício de sua dialética, Sócrates tivesse sido o racionalista que muitos imaginaram (inclusive

7. Platão. Apologia de Sócrates, 28e - 29a-e-d.

8. Ver a este respeito o que escreve Jacques Maritain no seu livro La philosophie morale: l'examen critique des grands systèmes. Paris: Gallimard, 1960.

9. Etimologicamente a palavra "maiêutica" significa "a arte da parteira". No Teeteto, Sócrates define seu trabalho como uma "arte maiêutica": "Quanto à minha arte maiêutica, ela tem todas as propriedades da arte das parteiras. Difere somente porque são os homens e não as mulheres que ajudo a dar à luz, pois é sobre o parto de suas almas, e não de seus corpos, que versa meu exame". Cf. Platão. Teeteto, 150, b. Cf. o que sobre isto escrevi no meu livro A morte de Sócrates. Uma mensagem para nosso tempo (1994), pp. 136-139. 


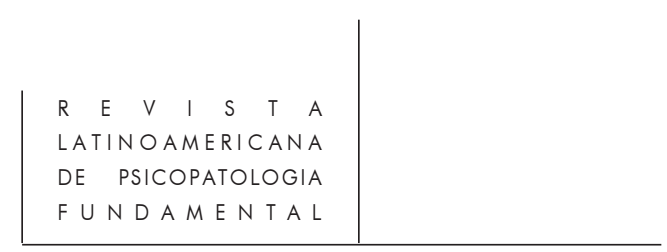

Nietzsche), ele, muito provavelmente, teria desanimado por causa dos fracassos sofridos nas tentativas feitas para definir os conceitos das virtudes. Os diálogos aporéticos (que são os diálogos da juventude de Platão) estavam sempre na procura de uma resposta inteligível para os enigmas da vida; e, neles, a dialética socrática, mesmo quando não encontrava o que procurava, porque alimentada pela força e pelo dinamismo de $\varepsilon \rho \circ$ (eros), ao invés de sucumbir ao ceticismo, como fazia a dialética sofística, não deixava jamais morrer o elã da procura. ${ }^{10}$

\section{A ciência do éthos}

Foi ética a grande preocupação filosófica de Sócrates. O que ele desejava, antes e acima de tudo, era aprofundar o sentido do Oráculo de Delfos: Conhece-te a ti mesmo ( $\Gamma \nu \varpi \tau \imath \sigma \varepsilon \alpha \nu \tau \circ \mathrm{v})$, dele tirando todas as consequiências para a ciência do ethos. Por causa disso, ele passou para a História como o fundador da Ética. E foi precisamente para fundamentar a conduta ética, que ele abraçou uma teoria da alma, na qual esta já se configura como "uma consciência que pensa e que age"

Esta maneira de ver a alma significa um avanço extraordinário para a filosofia antiga se comparada com o que, antes, foi dito pelos outros filósofos da Grécia Arcaica. Werner Jaeger diz que a originalidade da doutrina socrática sobre a alma está no fato de Sócrates ter visto, nela, "um $\pi \propto \theta$ os valorativo" que, em última análise, revela o sentido e o valor da vida e da existência humana.

Por causa disso, o conceito socrático de psyché (alma) reveste uma significação nova. "Cuidar da alma", para ele, tinha uma conotação ético-religiosa. Provavelmente, foi por causa dessa conotação que a concepção socrática de "alma" teve uma acolhida tão calorosa por parte dos pensadores cristãos, e que, até hoje, mesmo no vocabulário psicológico, a palavra "alma" lembra algo ligado ao mundo dos valores espirituais.

\section{Logos e Eros}

Indiscutivelmente, Sócrates era um entusiasta do Logos, e via, na inteligência, a mais nobre atividade do espírito. Por isso, dizia ele, a ciência é virtude, pois não conseguia imaginar que a verdadeira ciência $(\varepsilon \pi \imath \sigma \theta \eta \mu \eta)$ não fosse capaz de

10. A este propósito esclarece Henrique de Lima Vaz: “ ... o caráter aporético dos primeiros diálogos traduz um sábio recurso pedagógico ou, mais exatamente, psicagógico de Platão, na medida em que o "amor do saber" (philosophia) da alma pouco a pouco se fortalece, estimulado pelas interrogações que se levantam ao longo do caminho, até sentir-se capaz de empreender a escalada cuja descrição caberá aos diálogos da maturidade". Cf. Henrique de Lima Vaz, Platão revisitado. Ética e metafísica nas origens platônicas (1993), p.189.

11. Cf. J. Burnet. The Socratic Doctrine of the Soul (1929). 


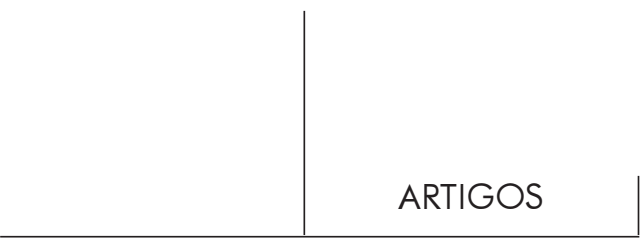

aperfeiçoar o homem, fazendo dele um virtuoso. Era através do conhecimento que se adquiria a técnica da virtude.

Não se deve esquecer, porém, que Sócrates era também um grande entusiasta de Epos. Ele dizia que sabia apenas que nada sabia, quando se tratava de explicar, com a inteligência, os enigmas do mundo e da vida. Daí sua perplexidade e espanto quando soube que a Pitonisa de Delfos dissera que ele era o mais sábio dos homens da Grécia. ${ }^{12}$ Depois de muito pesquisar para descobrir o sentido do oráculo, ele finalmente concluiu que, se era o mais sábio, era simplesmente porque sabia que não sabia. Ele só admitia conhecer, um pouco, as coisas do amor. É o que diz no Banquete: "Declaro nada saber senão as coisas do amor $(\tau \alpha \varepsilon \rho \omega \tau \imath \kappa \alpha)$ ". No Lisis, falando ao apaixonado Hipothalès, ele também afirma:

Ó filho de Jerônimo, Hipothalès, tu não precisas me dizer se, sim ou não, tu amas alguém. E o que sei, na verdade, é não somente que tu amas, mas que tu estás muito avançado no caminho do amor. Sob todos os outros pontos de vista não sou nada e nada valho, mas quanto a este, é como um dom que a Divindade me fez de ser capaz de reconhecer rapidamente um amante tanto quanto um amado. ${ }^{13}$

É por esta razão que nos recusamos a ver, em Sócrates, um puro intelectualista. Vimos que ao fazer da preocupação com a alma a tarefa fundamental de sua vida, ele próprio enfatizou algumas outras atividades anímicas, tais como: "ter zelo ardente de", "correr o risco de" e "enfrentar os perigos, inclusive a morte", atitudes estas que podem ser vistas como valiosos equivalentes do $\theta u \mu \circ \varsigma$ (thymós) homérico.

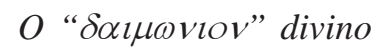

Depois, é preciso também não esquecer o que Sócrates diz sobre o seu " $\theta \varepsilon \imath$ เ

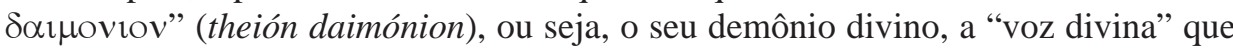
o guia na vida. No Tribunal, diante dos juízes, ele definiu este "daimónion" como um "sinal" do deus:

Muitas vezes, e em muitos lugares, me ouvistes dizer que me acontece não sei o que de divino e demoníaco ( ... ) Os inícios datam da minha infância: é uma voz que é por mim ouvida, e que, toda vez que isto acontece, afasta-me daquilo que estou eventualmente para fazer sem jamais me compelir para a ação. ${ }^{14}$

Note-se, pois isto é fundamental, que a "voz" que Sócrates ouve, e que denomina

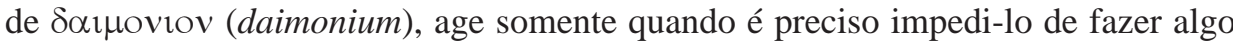

12. Platão. Apologia de Sócrates, 21a.

13. Platão. Lisis, 204b-c.

14. Platão. Apologia de Sócrates, 31d. 


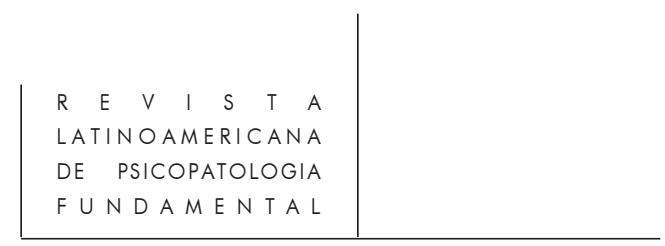

que possa verdadeiramente prejudicá-lo. A "voz" não é uma "força compulsiva" que o leva a fazer o que ele não quer. É uma espécie de escudo que o protege quando enfrenta situações para as quais não está devidamente preparado. Daí alguns autores verem nele a "simples voz da consciência", ou o sentimento daquilo que é conveniente. ${ }^{15}$

Podemos, portanto, concluir que, além da inteligência, Sócrates valorizou muitíssimo as potências afetivas da alma, entre as quais sobressai o desejo. É verdade, como observa Jean Frère, que estas potências, que nos movem, ainda não encontraram, na doutrina socrática, "formas substantivas de expressão", mas foram traduzidas pelo dinamismo de alguns verbos significativos, tais como: "preocuparse com" ( $(\pi \imath \mu \varepsilon \lambda \varepsilon \imath \sigma \alpha \imath)$, "ter zelo ardente de" ( $\pi \rho \circ \theta \cup \mu \varepsilon \imath \sigma \tau \alpha \imath)$, "arriscar-se contra"

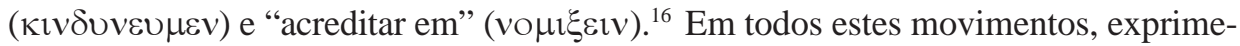
se muito mais o elã profundo do coração do que o dinamismo da inteligência. Mas

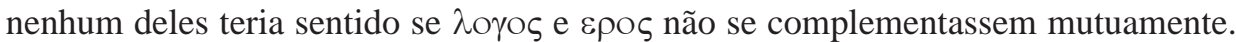
É o que aparece, de modo mais claro, se passarmos, agora, a considerar o que Platão nos diz sobre o desejo.

\section{O desejo na Filosofia de Platão}

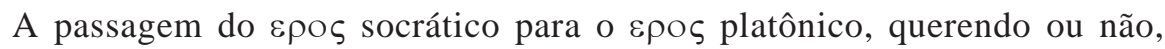
confronta-nos com o célebre "problema de Sócrates" 17 . Quem é o verdadeiro Sócrates? A questão foi reavivada, no início de nosso século, pela Escola escocesa (Burnet e Tylor). Os especialistas querem saber se podemos atribuir a Sócrates a doutrina dos diálogos platônicos, não só a dos primeiros diálogos, senão também a de alguns dos diálogos da maturidade, ou se, pelo contrário, Sócrates não seria, apenas, um personagem fictício, criado por Platão, para ser o grande protagonista de suas idéias filosóficas? Indubitavelmente, Platão é a fonte mais valiosa e fecunda, comparado com Xenofonte, Aristófanes e Aristóteles, para resgatar a vida e a doutrina de Sócrates. Mas não se pode esquecer que ele idealizou a figura de seu mestre.

Aqui, também, virtus in medio, vale dizer, a virtude está no meio, pois como esclarece Henrique de Lima Vaz: "O cotejo e a mútua complementação das fontes nos permitem traçar as linhas de um ensinamento propriamente socrático (...) e nos

15. Cf. A. Gomez-Lobo. La ética de Sócrates (1989), pp. 75-79. Veja-se sobre isto o que escreve Giovanni Reale na História da Filosofia Antiga (1993), vol. I, p. 299, e o que também escrevi no meu livro A morte de Sócrates. Uma mensagem ética para nosso tempo (1994), pp. 219-225.

16. Cf. Jean Frère. Les grecs et le désir de l'être (1981), pp. 104-105.

17. Permito-me, mais uma vez, enviar o leitor ao resumo que apresento do "problema socrático", no meu livro A morte de Sócrates. Uma mensagem ética para nosso tempo (1994), pp. 75-85. 


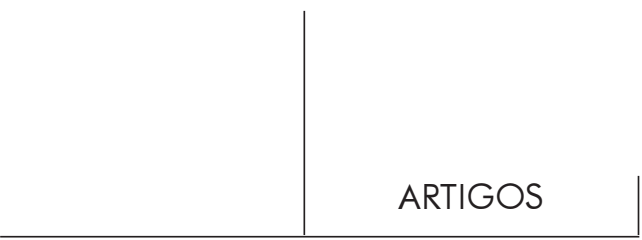

permitem igualmente medir a distância enorme que separa o quotidiano da pólis, no qual se move o ensinamento socrático, das alturas vertiginosas, até onde se eleva a teoria platônica" ${ }^{18}$.

\section{a) O Éros no "Banquete" de Platão}

Para melhor avaliar o que escreve Platão sobre Eros no Banquete, lembremos rapidamente o contexto cultural do diálogo. Os simpósios helênicos têm uma longa história. Neles, os $\alpha \rho \imath \sigma \tau o r$ (os eupátridas ou bem-nascidos) da Grécia Arcaica homenageavam seus hóspedes ilustres. Neles, também, os poetas reconstruíam a História da Grécia nos seus poemas épicos. Platão continua e inova esta tradição, quando escolhe a forma estilística do "Simpósio" (Banquete) para apresentar sua doutrina filosófica sobre Epos.

O Banquete é inegavelmente um dos mais belos diálogos de Platão e uma das coisas mais lindas que já se escreveu sobre o amor em toda a História da Literatura Universal. Os convivas, que participam do Banquete, são pessoas importantes e representam as diversas classes da cultura helênica. Fedro é retórico, Pausânias é discípulo de um sofista, Erixímaco é médico, Aristófanes é poeta e Agatão é o vencedor do concurso literário, em cuja homenagem se fazia o simpósio. O texto resgata das brumas da memória e das incertezas da lembrança, os discursos de épocas remotas. Ele é de grande riqueza estilística e, nele, se encontra uma impressionante variedade de recursos literários. Como observa Werner Jäger:

No Banquete, Platão estende uma ponte audaciosa sobre o abismo que separa o apolíneo do dionisíaco. Para ele, sem o impulso e o entusiasmo inesgotáveis e sem cessar renovados das forças irracionais do homem, jamais seria possível atingir o cume daquela transfiguração suprema que o espírito adquire ao contemplar a idéia do Belo em si. ${ }^{19}$

Os elogios de Eros

Antes de Sócrates, os demais convivas fizeram o elogio de E $\rho$ os, enaltecendoo como o mais antigo dos deuses. Para Fedro, em Epos estava o segredo do herói

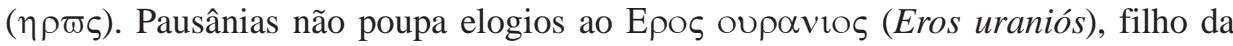
Afrodite Urânia, enquanto o $\varepsilon \rho \circ \varsigma \pi \alpha \nu \delta \varepsilon \mu \circ \varsigma$ (Eros pandemós) é de natureza vil e efêmera. Erixímaco, retomando a antiga tradição de Hesíodo, vê, em Epos, a força

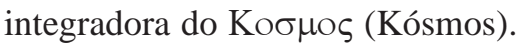

18. Cf. Henrique de Lima Vaz. Platão revisitado (1993), p. 183. Grifos nossos.

19. Cf. Werner Jaëger. Paideia (1948), vol. II, p. 219. 
O mito do andrógino

Aristófanes, analisando o mito do andrógino, foi quem melhor discursou entre aqueles que falaram antes de Sócrates. Epos, diz ele, é desejo de unidade e de plenitude. Para se ter uma idéia da sua natureza é preciso partir das origens da própria Humanidade.

Inicialmente, a espécie humana possuía três espécies de seres (os machos, as fêmeas e os machos-fêmeas ou andróginos). Estes, sentindo-se mais fortes por causa de sua constituição dupla, conspiraram contra Zeus. O deus, porém, não quis exterminá-los para não ser privado dos sacrifícios que eles lhe ofereciam, mas cortouos pelo meio e mandou que Apolo curasse as feridas, costurando cada metade e, nelas, deixando a cicatriz. Mandou que voltasse a cabeça de cada metade para o lado do corte, a fim de que, vendo a cicatriz, eles se tornassem mais modestos. As metades, lamentando terem perdido sua outra metade, a ela se agarravam e nada conseguiam fazer senão lamentar o que perderam. Como os órgãos sexuais ficavam na parte de trás, elas não se reproduziam e, na tristeza em que se encontravam, pereciam. Zeus, então, mandou virar os órgãos sexuais para frente e a reprodução pôde ser feita. ${ }^{20}$

Não deixa de ser significativo que Aristófanes condicione o exercício da sexualidade genital dos andróginos a um corte que separa os indivíduos, os quais se encontravam unidos numa fusão originária indiferenciada, sem poderem se distinguir um do outro. Esta passagem de uma fusão originária (que Freud chamaria de narcísica) para o amor de um objeto poderia ser articulada ao que a psicanálise ensina sobre o desenvolvimento da sexualidade humana, na qual a castração tem uma função estruturante (simbolizada por vários cortes e separações, desde a separação do nascimento e do corte do cordão umbilical até a separação definitiva da morte) para desfazer a fusão narcísica originária mãe-filho e possibilitar, pela mediação do Édipo, a realização da identidade sexual.

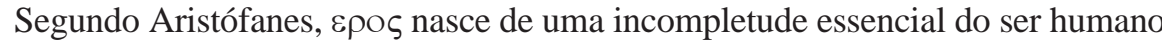
e não se pode saber o que ele é sem se levar em consideração esta natureza humana. A incompletude é fruto de um corte sem o qual o homem se perderia numa indiferenciação originária, na qual nutria a ilusão de ser completo. Além disso, o "bi-ser originário" não podia se ver, pois tinha duas faces iguais e uma só cabeça. Faltava-lhe a distância, que lhe permitiria reconhecer-se duplo. Para Aristófanes, a escolha de objeto, homo ou heterossexual, dependia do que cada um tivesse sido na

20. No que se refere aos estudos psicanalíticos sobre o mito do andrógino, conheço e consultei, apenas, o trabalho de Claude Van Reeth, "O banquete ou a ilusão amorosa. Leitura de Freud à luz do Banquete” (1970), pp. 107-123. 


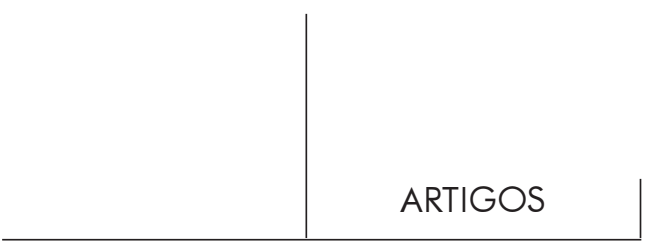

origem. Da separação do objeto primordial resultava uma incessante busca, sempre renovada porque sempre fracassada, através de uma série infinda de objetos substitutivos. Nenhum deles, contudo, preenchia plenamente a falta.

Detive-me um pouco no discurso de Aristófanes porque ele levanta questões interessantíssimas a respeito da origem de $\varepsilon \rho \circ \varsigma$, da escolha do objeto sexual e de sua finalidade, questões estas que certamente poderiam e mereceriam ser mais aprofundadas do ponto de vista psicanalítico. Mas não vou fazê-lo agora. Deixo, pois, o mito do andrógino e continuo a leitura do Banquete.

Agatão, retomando a tradição, fez de Epos o melhor dos deuses, que ordena o mundo desordenado dos desejos e é fonte de vida, de criatividade e de beleza. Finalmente a palavra foi dada a Sócrates, pois seu discurso era ansiosamente esperado por todos.

O discurso de Sócrates

Sócrates começa afirmando (o que causa um certo mal-estar nos presentes) que $\varepsilon \rho \circ \varsigma$ não é um deus, porque é desejo. E o desejo é sempre desejo de alguma coisa que não se tem, ou que se tem, mas se teme perder no futuro. O desejo necessariamente nasce da falta. Mas se Epos não é um deus, o que é então? Antes de tentar responder a esta pergunta, Sócrates, para tornar seu discurso mais aceitável pelos presentes, diz que o ouviu da boca de Diotima, a sacerdotisa de Mantinéia ${ }^{21}$, que era sábia nas coisas do amor. Pois bem, foi esta sacerdotisa quem o "iniciou" no mistério de $\varepsilon \rho \circ \varsigma$, revelando-lhe, antes de tudo, que "éros" era um "grande daimon" $(\delta \alpha \imath \mu \omega \vee \mu \varepsilon \gamma \alpha \varsigma)^{22}$, um ser intermediário ( $\left.\mu \varepsilon \tau \imath \xi v\right)$ entre o mortal e o imortal, entre os deuses e os homens, com a missão de "fazer conhecer e de transmitir aos deuses o que vêm dos homens e aos homens o que vêm dos deuses"23.

Platão acrescenta ainda que é graças a esta natureza intermediária do "daimon" que os deuses podem entrar em relação com os homens e conversar com eles, seja durante a vigília (como no caso de Sócrates) seja durante os sonhos (nos quais os deuses, freqüentemente, mandam suas mensagens aos mortais). De natureza intermediária, \&pos é um traço de união entre o mundo físico e o mundo inteligível. E foi precisamente para esclarecer esta natureza intermediária de E $\rho \circ \varsigma$ que a sacerdotisa de Mantinéia revelou o mito do seu nascimento.

21. Provavelmente a figura de Diotima (sobre a qual paira o véu do mistério, pois não se sabe nada de historicamente comprovado sobre ela, apenas que era uma sacerdotisa de Mantinéia) foi uma criação literária com a qual Platão quis proteger Sócrates da inveja e do ciúme dos colegas e convivas que, antes dele, falaram no simpósio.

22. Platão. O banquete, 202d-e.

23. Idem, ibidem. 
O mito do nascimento de Epos

No dia do aniversário do nascimento da deusa Afrodite, os deuses lhe deram uma grande festa nos jardins de Zeus. Entre os convidados, encontrava-se Пopos (o deus do recurso, da riqueza e da abundância) e Пevvi (a deusa da pobreza). ${ }^{24}$ No fim do jantar, a deusa da pobreza aproximou-se do local da festa para mendigar. Foi, então, que percebeu Пороร, embriagado pelo néctar (pois vinho ainda não existia!), dormindo nos jardins. Na sua penúria, ela pensou, então, em ter dele um filho. Deitou-se ao seu lado e concebeu Epos que é, portanto, filho do deus Recurso e da deusa Pobreza.

Segundo a natureza da mãe, ele é pobre e nem sempre mostra-se delicado e belo como a maior parte das pessoas imagina, mas, pelo contrário, é rude, malvestido, descalço, não tem lar, dorme por terra e sem cobertas, à luz das estrelas e no solar das portas ou nas ruas, e tudo isso porque, tendo a natureza da mãe, partilha a vida da indigência. Mas, em revanche, de conformidade com a natureza do pai, ele está sempre na espreita de tudo o que é belo e bom, pois é valente e vai sempre avante com todas as suas forças; é caçador esperto, freqüentemente tramando ardis, de pensamento curioso e rico em idéias e astúcias, ele passa toda sua vida a filosofar, hábil como um feiticeiro, mago e sofista. ${ }^{25}$

As duas faces de $\varepsilon \rho \circ \varsigma$

Aí estão, narradas na linguagem do mito (que revela ocultando e oculta revelando), as duas faces de $\varepsilon \rho \circ \varsigma$, sua face de grandeza e sua face de miséria. Enquanto filho da pobreza, ele é, antes de tudo, um grito de indigência e de indigência metafísica. Nada mais contrário à sua natureza do que a pretensão de poder bastarse a si mesmo. O egoísmo que fecha o homem dentro de si mesmo, sob qualquer uma de suas formas, compromete o amor, pois mata a fecundidade de $\varepsilon \rho \circ \zeta$. E é precisamente esta fecundidade que a sua outra face revela. Ele é também filho da

24. Se a tradução de $\pi \varepsilon v \imath \alpha$ por "pobreza" não tem nenhuma dificuldade, o mesmo não acontece com a palavra $\pi$ o 0 ऽ que tradicionalmente foi traduzido por riqueza, abundância e opulência em contraposição à pobreza de $\pi \varepsilon v \imath \alpha$. Marcilio Ficino sugeriu, na excelente tradução latina que fez do Banquete, que se traduzisse a dupla $\pi$ o $\rho \circ \varsigma-\pi \varepsilon v 1 \alpha$ por "cópia e inópia". Há, porém, quem prefira traduzir $\pi$ o $\rho \varsigma$ $\varsigma$ por "saída". De fato, os "poros" são aberturas e saídas para a transpiração. Assim sendo, eles simbolizariam as saídas para os apuros e dificuldades da vida,

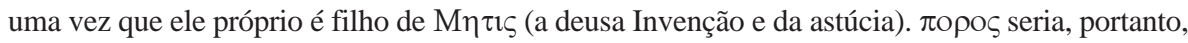
o engenhoso, o inventivo, o expedito, Leon Robin propôs que se traduzisse por "Expédient" (Expediente). Cf. A.G. Robledo. Platón (1993), pp. 91-92.

25. Cf. O banquete, $203 \mathrm{~d}$. 


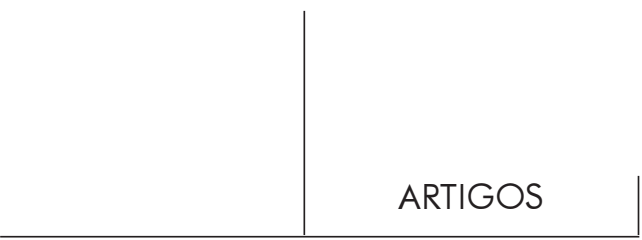

riqueza e isto deve ser entendido em termos de ser e de doação de ser. Epos não é só desejo, ele é também doação, dom de si mesmo. Mesmo enquanto desejo, ele é desejo de promoção do outro. Ninguém é tão pobre que não tenha algo a dar de si. O simples estar no mundo já é um mínimo de bondade oferecida aos outros.

Depois de definir a natureza de $\varepsilon \rho \circ \varsigma$, Diotima revela a Sócrates o segredo de seu verdadeiro objeto. Eis o diálogo:

D: - O objeto do amor, Sócrates, não é o belo, como tu imaginas ...

S: - Então, o que é?

D: —É a procriação na beleza.

S: $\quad$ - Não é possível.

D: - Pois é, absolutamente.

S: - Então, por que precisamente a procriação?

D: - Porque a procriação é o que um ser mortal pode comportar de eterno e

de imperecível. Ora, este desejo de imortalidade... está forçosamente unido ao desejo do que é bom, uma vez que o objeto do amor é a posse perpétua do que é bom.

Assim, portanto, o objeto do amor é também forçosamente a imortalidade. ${ }^{26}$

Resumindo, o objetivo de Eros é a procriação na beleza, tanto a corporal quanto a espiritual. Fundamentalmente, eros é dese--×jo de imortalidade. É tendo em vista este desejo de imortalidade que Diotima passa a descrever a ascensão dialética da alma para a intuição da Beleza Suprema, na qual se coroa o desejo de imortalidade.

A ascensão dialética da alma

Diotima adverte que esta escalada dialética da alma que, de degrau em degrau, sai à procura da Beleza em si (que é, ao mesmo tempo, o Bem Absoluto) é o que existe de mais alto e de mais sublime no mistério de Eros. Na dinâmica desta ascensão, a alma é atraída pela beleza dos objetos que a fascinam e é movida pelo desejo de procriação e de imortalidade. À medida que a ascensão se realiza, há mudança nos objetos e na natureza da procriação. Primeiramente, é a beleza dos corpos e o desejo de procriação biológica que dinamiza a alma. Depois, a beleza da alma e seu desejo de procriação espiritual. Em seguida, vem a beleza da ciência e, finalmente, a beleza suprema da Idéia do Belo.

A ascensão é dirigida pelo Logos que vai revelando os diversos sentidos dos objetos percebidos. Os degraus desta ascensão dialética correspondem aos quatro planos fundamentais da visão platônica do mundo e do homem, vale dizer, o plano do corpo na harmonia de sua forma visível, o plano da alma na riqueza de sua fecundidade criativa, o plano da ciência discursiva na limitação de seus objetos e, finalmente, o plano da intuição das Idéias, onde se esconde o segredo da essência 


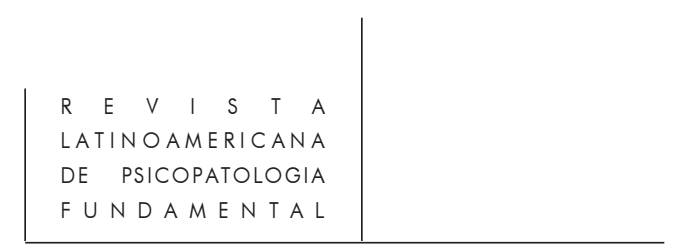

dos seres. ${ }^{27}$ À medida que vai escalando estes planos, a alma cada vez mais se afasta do sensível e se aproxima do inteligível até mergulhar na contemplação da Beleza em si, objeto último de $\varepsilon \rho \circ \varsigma$, Beleza esta absolutamente idêntica a si mesma, eterna e divina. Com este qualificativo de divino $(\theta \varepsilon ı v)$, Platão quer dizer que, no Belo absoluto, está a origem e o fim da dialética que antes de ser ascensiva foi, primeiramente, descensiva. ${ }^{28}$

Para terminar esta rápida leitura do Banquete, eu gostaria de perguntar: por que Platão deu um lugar de tanto destaque à Idéia da Beleza, identificando-a com a Idéia do Bem, que, para o grego, sempre representou o segredo da $\varepsilon v \delta \imath \mu o v \imath \alpha$ (eudaimonia), ou seja, da felicidade? O Banquete tinha também uma finalidade educativa. Na crise da modernidade grega, se fazia necessário repensar os fundamentos da $\Pi \alpha 1 \delta \varepsilon \imath \alpha$ ameaçada pelo relativismo dos sofistas. ${ }^{29}$ Ora, o ideal do $\kappa \alpha \lambda \circ \zeta \kappa \alpha \iota \alpha \gamma \alpha \theta$ o sempre fascinou a alma grega. Mas poder-se-ia se dizer também, de modo mais simples, que esta primazia da Beleza deve-se ao fato de ser ela, a Beleza, "o jeito que a verdade encontrou de se fazer mais querida" ${ }^{30}$. Deixemos o Banquete e vejamos, agora, o que nos diz Platão sobre epos no Fedro que, incontestavelmente, é, também, um dos seus diálogos mais belos e mais poéticos.

27. Cf. Henrique de Lima Vaz. "Amor e conhecimento" (1956), p. 233.

28. Os especialistas não são unânimes ao interpretar a etapa final desta "iniciação" de Sócrates no mistério de $\varepsilon \rho \circ \varsigma$, ou seja, a escalada dialética da alma que, de degrau em degrau, sai à procura da

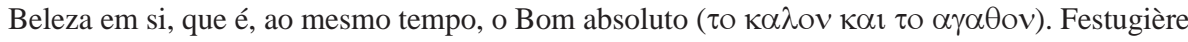
é de opinião que esta intuição não é da ordem do conhecimento discursivo. Tratar-se-ia, de preferência, de algo que seria da ordem do êxtase ou de uma contemplação mística, um sentimento

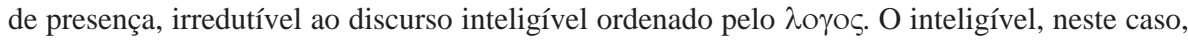
seria sentido, antes que visto ou conhecido. Já Henrique de Lima Vaz opina que a intuição do Belo é uma ciência do Belo. O Banquete, como todos os outros diálogos de Platão, busca no conhecimento da Idéia do Belo, o coroamento inteligível do esforço que impulsiona a ascensão dialética da alma. O Belo, que Platão apresenta como o objeto último de $\varepsilon \rho \circ \varsigma$, é um valor em cuja plenitude inteligível se resolvem as aporias dos objetos particulares e contingentes que são também objeto de $\varepsilon \rho \circ \varsigma$. Ou, dito de outro modo, Platão resolveu a aporia de $\varepsilon \rho \circ \varsigma$ sem fugir para nenhuma solução mística, mas dentro da metodologia que era própria do seu itinerário filosófico. A onda da paixão e do entusiasmo que envolve o "Banquete" não o torna menos platônico do que os outros diálogos. O elogio de $\varepsilon \rho \circ \varsigma$, que Platão faz no Banquete, em nada cede ao rigor do $\lambda$ oyos platônico. Veja-se, a este propósito, o livro de A.J. Festugière. Contemplation et vie contemplative selon Platon. Paris: Vrin, 1950 e Henrique de Lima Vaz. "Amor e conhecimento. Sobre a ascensão dialética no 'Banquete"” (1956), pp. 225-242.

29. Ver a este propósito as observações de Werner Jaëger na monumental Paideia (1948), tomo II, pp. 228-240.

30. Foi isto que, certo dia, escreveu meu amigo Daniel Lima numa mensagem que me é muito cara. 


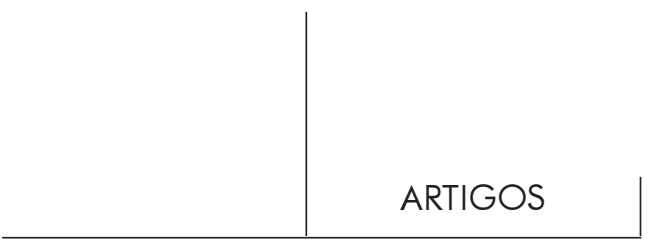

b) O Epos no “Fedro" de Platão

A teoria do E $\rho \circ$ s, em Platão, é indissoluvelmente unida à sua doutrina da alma, pois à medida que ele foi aprimorando a sistematização teórica da $\psi v \chi \eta$ (psyché), foi sentindo também necessidade de aprofundar a natureza e as funções de $\varepsilon \rho \circ \varsigma$.

A doutrina platônica da alma humana

Quando escreveu o Banquete, Platão já dispunha de uma teoria da alma sistematizada no Fédon. Mas a doutrina do Fédon não é sua última palavra sobre a alma humana. Marcado pela oposição radical entre a alma e o corpo e pela visão do corpo como túmulo da alma $(\sigma \varpi \mu \alpha-\sigma \eta \mu \alpha)$, o Fédon apresenta-nos uma "visão unitária" da alma, em que esta aparece essencialmente constituída pela inteligência. Os desejos e as paixões têm sua sede no corpo e não na alma. Daí porque, enquanto unida ao corpo, a alma nada pode conhecer da sua pureza essencial. O mundo da verdadeira ciência $(\varepsilon \pi \imath \sigma \theta \eta \mu \eta)$ está fora do seu alcance, pois no esquecimento do essencial, só lhe resta o mundo da opinião, ou seja, o mundo da $\delta \circ \chi \alpha$. $^{31}$

Filosofar, então, outra coisa não pode ser senão um contínuo preparar-se para a morte, pois é na morte que o filósofo se liberta finalmente da prisão do corpo. Esta visão da filosofia como lenta preparação para a morte supõe o novo conceito de saber introduzido por Sócrates na cultura helênica. Até então, os filósofos

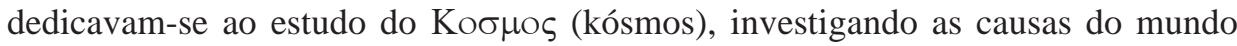
exterior, ou seja, da $\Phi$ v $\iota \varsigma$ (physis). Sócrates levou o homem a transpor o campo de suas pesquisas para o mundo da sua interioridade. ${ }^{32}$

31. Grube, no interessante estudo que escreveu sobre o pensamento de Platão, vê no Fédon um intelectualismo puro, inteiramente oposto à intensidade emocional e afetiva do Banquete. Os temas centrais do Fédon são a morte e a imortalidade. No Banquete, Platão fala, de preferência, sobre o amor, a beleza e a vida. O intelectualismo puro e frio do Fédon se divorcia da vida. E, com certa ironia, Grube acrescenta que este intelectualismo tem como objetivo: "a conservação eterna da alma no frigorífico das Formas absolutas eternamente congeladas.” Cf. G.M.A. Grube. El pensamiento de Platon (1987), p. 202. É verdade que nem todos os estudiosos de Platão concordam com esta opinião de Grube. Não faltam os que, tendo como referência a imortalidade da alma, opinam que o modelo unitário da alma apresentado no Fédon é mais platônico do que o modelo tripartido do Fedro e da Republica. Ver sobre isto o que escreve Anastácio Borges de Araújo Júnior na sua tese de Mestrado sobre "Platão e Freud: duas metáforas da alma humana". Universidade Federal de Pernambuco, Recife, março de 1999.

32. Sobre a filosofia como preparação para a morte e a oposição $\sigma \omega \mu \alpha-\sigma \eta \mu \alpha$, remeto o leitor ao que escrevi no meu livro A morte de Sócrates. Uma mensagem ética para nosso tempo (1994), pp. 120-123. 


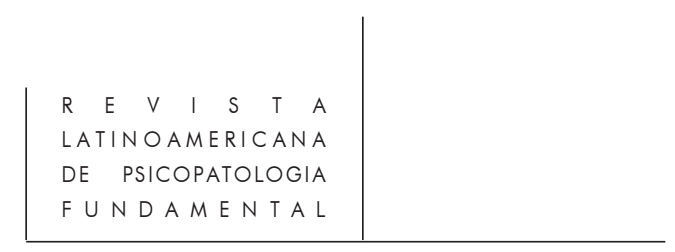

Com a introdução do Mundo das Idéias, Platão abriu a rota da segunda navegação ( $\delta \varepsilon \cup \tau \varepsilon \rho \varsigma \varsigma \pi \lambda \circ \cup \varsigma)$. Em vez de separar, ele agora articula o mundo sensível ao mundo inteligível. Isso teve uma repercussão imensa sobre sua doutrina da alma.

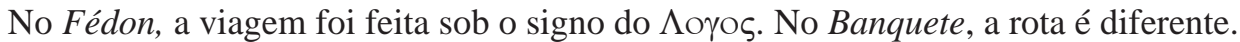
Ela é feita sob o signo de epos. A meta que se propõe o filósofo não é mais desvincular a alma dos prazeres e dos desejos, mas fazê-la elevar-se, através deles, até a mais alta forma de conhecimento, que é a visão $(\theta \varepsilon \omega \rho \imath \alpha)$ da Beleza em si, fonte da procriação espiritual, que é o objeto último de epoç. Daí a necessidade que sentiu Platão de estabelecer, no Banquete, uma outra estrutura da alma, vale dizer,

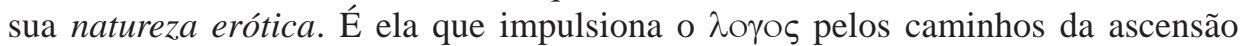

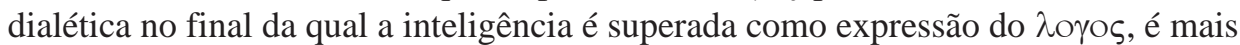
do que $\lambda$ oyo $^{33}$, para se tornar "visão" intuitiva da Beleza em si. ${ }^{34}$

Mas a passagem do Banquete ao Fedro foi feita pela mediação da República. Ora, neste diálogo, Platão apresenta e defende o modelo tripartido da alma e distingue, nele, três partes: a "alma concupiscível" constituída pelos desejos irracionais, a "alma irascível" constituída pela coragem e pelos sentimentos ardorosos (thymós) e a "parte intelectiva" constituída pelo "nous", ou seja, pela inteligência. Estas três partes da alma correspondem ao que hoje nós chamamos as três estruturas fundamentais do ser humano, ou seja, a estrutura corpórea, psíquica e espiritual. Assim sendo, três são os princípios que movem a alma: o princípio racional

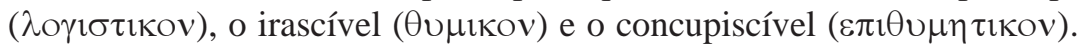

Esta divisão tripartida representa um grande progresso para a doutrina filosófica da alma humana. Agora, pode-se dizer que a alma que pensa é a mesma que se apaixona e que deseja. Os seus conflitos não são motivados necessariamente pela oposição ao corpo. Eles têm suas causas e seus motivos dentro da própria alma. Está preparado, assim, o campo para a idéia do conflito intrapsíquico.

Platão retoma, nesta visão tripartida, o $\theta$ uno homérico e o coloca, como parte constitutiva da alma, a serviço da razão. É ele o elemento que articula a parte racional com a parte irracional da $\psi v \chi \eta$. Ou, dito de um modo paradoxal, ele é o pensamento que deseja e o desejo que pensa, os quais harmonizam a diferença dos contrários na unidade plurivalente da alma humana.

Na visão tripartida da alma, Platão não esquece a parte concupiscível, "na qual se encontram aqueles desejos" que não se submetem ao controle da razão. ${ }^{35}$ No

33. Cf. Luigi Stefanini. Platone. I (1949), pp. 229-232. Citado por Henrique de Lima Vaz. "Eros e logos" (1952), p. 167.

34. Ver sobre isto o belo trabalho de Henrique de Lima Vaz. "Eros e logos. Natureza e educação no Fedro platônico" (1952), p. 165.

35. Cf. Platão. Gorgias, 453a-d. 


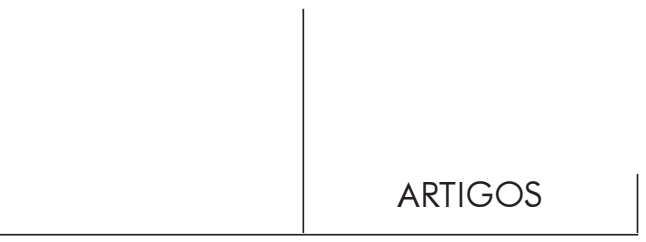

livro IX da Republica, ele faz uma descrição minuciosa dos "desejos selvagens" primitivos e irracionais. Eis como ele os descreve:

Quais são esses desejos dos quais queres falar? - São aqueles que despertam por ocasião do sono, todas as vezes que dorme a parte da alma, cujo papel é raciocinar e comandar pela doçura a outra [parte]; enquanto a parte bestial e selvagem, tendose recupletado de comida e de bebida, agita-se e, afastando o sono, tenta ir em frente e satisfazer suas inclinações. Sabes, muito bem, que em tal ocorrência não existe audácia diante da qual ela recue, como se estivesse desligada e desembaraçada de toda vergonha e de toda reflexão. Nem mesmo diante da idéia de querer unir-se à sua mãe [incesto], ou a quem quer que seja, homem, divindade, animal; de manchar-se com qualquer assassinato, nem de abster-se de qualquer alimento [canibalismo]. Numa palavra, sob qualquer ponto, não lhe falta insensatez nem indiferença à vergonha. ${ }^{36}$

Não deixa de ser impressionante que Platão, tantos séculos antes de Freud, tenha feito a extraordinária descoberta que, nos sonhos, esses nossos “desejos selvagens" mais primitivos e mais tenazes (tais como o incesto, o assassinato e o canibalismo) encontram uma certa forma de satisfação.

De posse desta nova teoria da alma, Platão retoma, no Fedro, para aperfeiçoála, a doutrina do epos. Vejamos o essencial.

A doutrina do amor no Fedro

O cenário do diálogo é descrito, logo no início, com um toque da mais pura poesia. Sócrates e Fedro, num resplandescente dia de verão, depois de fazerem um belo passeio fora dos muros da cidade, sentam-se na relva de um alto plátano, junto do qual corre o pequeno regato Illisso, e conversam sobre o discurso que o retórico Lisis fez sobre o amor. Lisis era um sofista que se deleitava em fazer discursos

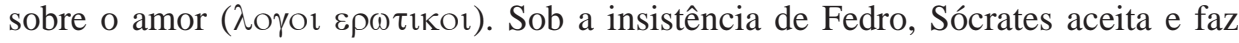
uma paródia do discurso de Lisis e, de modo mais burlesco do que sério, afirma que o amor-paixão é egoísta e prejudicial para o amado e, uma vez que procura apenas satisfazer seu apetite, pode ser comparado ao que o lobo sente pelo cordeiro. É, portanto, degradante para o amante. "Eis, caro rapaz, o que é necessário ter em mente; deves saber que o amor de um homem apaixonado não provém de um sentimento benévolo, mas, como o apetite ao comer, provém da necessidade de satisfazê-lo. Como o lobo ama o cordeiro, ama o apaixonado o seu amado"37.

Depois de ter feito esta paródia, Sócrates se prepara para ir embora, mas é advertido pelo seu $\delta \alpha \iota \mu$ ov (dáimon) interior de não partir, pois, tendo injuriado a 


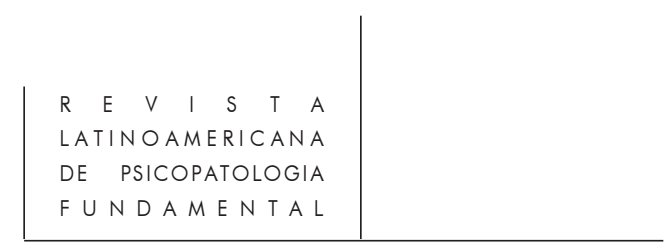

¿po $\varsigma$ no discurso que acabara de fazer, era absolutamente necessário que ele fizesse uma reparação ou, como diziam os gregos, uma $\pi \alpha \lambda \iota v \omega \delta i \alpha$ (palinódia), ou seja, uma retratação do que dissera para expiar seu tremendo pecado ( $\delta \varepsilon ı v o v ~ \alpha \mu \alpha \rho \tau \eta \mu \alpha)$. Sócrates se propõe, então, a fazer um segundo discurso, que é um verdadeiro elogio da loucura, do delírio, da paixão, e de tudo aquilo que Platão reuniu sob o nome de Mavia (Mania).

Os delírios divinos

Como os Gênios ctônios, as Erínias e a deusa Até (deusas violentas, ministras da vingança divina), a "Mania" era uma personificação da desrazão e tinha o poder de enlouquecer as pessoas que desdenhavam os ritos ou as ordens dos deuses. Os gregos conheceram a loucura causada pelas doenças e pelas deusas da vingança. Por isso mesmo, os loucos, na Grécia Antiga, eram olhados com muita ambigüidade: de um lado eram evitados e socialmente discriminados, mas, de outro lado, eram vistos com temor porque, por trás da loucura, se escondia algo que vinha dos deuses. Todavia, a "Mania" ou o "delírio" que Sócrates elogia no Fedro é de natureza diferente, pois tem origem divina e é um verdadeiro dom dos deuses. Entre os bens que os deuses imortais destinaram aos homens mortais, os maiores foram dados através de um delírio: o dom da adivinhação para penetrar nos segredos do futuro, o da poesia para resgatar o passado, o delírio ritualístico para livrar a cidade das calamidades e o do amor pela verdade, que fazia do homem um amigo da sabedoria, um filósofo. São quatro, portanto, os tipos de delírio divino apresentados no Fedro: o profético, o catártico ou ritualístico, o poético e o amoroso ou erótico. Cada um deles é relacionado com um deus respectivo. O delírio profético e catártico é obra de Apolo, o poético é inspirado pelas Musas e o erótico inspirado pela divina Afrodite.

O delírio profético

No delírio profético, as pitonisas, sacerdotisas de Apolo, previam o futuro. Ora, o futuro só aos deuses pertence. Seu conhecimento é inacessível aos mortais. Se as pitonisas previam o futuro, é porque, para tanto, recebiam um dom divino. Nos momentos habituais da vida cotidiana, as pitonisas "praticavam coisas sem importância, ou nada faziam"38. Os dons divinatórios, elas só os recebiam em estado de "entusiasmo", vale dizer, quando estavam "repletas" do divino. Léon Robin esclarece que isto não significava que o deus habitasse a pitonisa, mas que ela saía fora de si, na hora do "entusiasmo", e era manipulada pelo deus que dela fazia "um verdadeiro instrumento de seus oráculos"39.

38. Platão. Fedro, 244b.

39. Cf. Léon Robin. La théorie platonicienne de l'amour. Paris: PUF, 1964. 


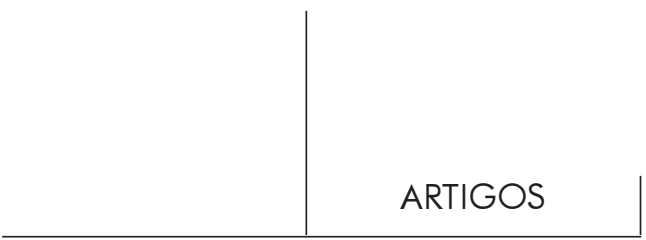

Numa época em que os gregos viviam sufocados por uma "cultura da culpa"40, conhecer o futuro era uma verdadeira necessidade psicológica, embora, numa de suas máximas, Pítaco, um dos sete sábios da Grécia, tivesse advertido: "É terrível conhecer o que acontecerá, mas conhecer o que aconteceu dá segurança" ${ }^{41}$.

Os oráculos nunca eram proferidos de forma clara, mas sempre de modo obscuro, como se o divino que revelava o oculto devesse, de novo, ocultá-lo no momento mesmo em que o revelava. Da mesma forma, a linguagem da pitonisa mergulhava num lusco-fusco, em que o racional e o irracional se misturavam. Na loucura profética, algo se produzia que era da ordem do saber e da verdade, embora esse saber passasse por uma linguagem desarrazoada que, nem por isso, a desqualificava. Pelo contrário, no Timeu, Platão diz que não se pode ter revelação divina quando se está no bom senso. Para tanto, é preciso o sono ou a loucura. ${ }^{42}$ Mas é a razão, no seu bom senso, que descobre o sentido das palavras proferidas pela desrazão do delírio. ${ }^{43}$

Como eram escolhidas e preparadas as pitonisas para exercerem semelhante função? Quase nada se sabe a este respeito. Plutarco diz que eram pessoas simples e sem instrução. Havia um meticuloso ritual de preparação para que a pitonisa entrasse em transe: ela se banhava com água especial, bebia da água sagrada, perfumava-se com folhas de louro e impregnava-se com a fumaça que era exalada pelas folhas de louro queimadas; depois a pitonisa descia até à cavidade misteriosa do Templo para tocar o o $\mu \rho \alpha \lambda$ os (o "umbigo"), como era chamado o centro de Delfos, centro do Mundo. ${ }^{44}$ Junito Brandão observa a este respeito que a palavra cavidade, em grego, se diz $\sigma \tau$ ¡ $\mu$ tov e pode significar também "vagina". Portanto, a descida da pitonisa à cavidade misteriosa do Templo e o fato de tocar o "omphalós", representado por uma pedra, tudo isso pode ser uma figuração de uma "união" da sacerdotisa com o deus Apolo. ${ }^{45}$

O delírio purificatório

Na loucura dos ritos purificatórios também havia uma manifestação do delírio "hierofântico", cuja finalidade era acalmar a cólera dos deuses nas grandes calamidades públicas. Este tipo de loucura ritualística imediatamente faz pensar nas

40. Cf. E.R. Dodds. Os gregos e o irracional (1984).

41. Cf. Giovanni Reale. História da Filosofia Antiga (1993), vol. I, p. 185.

42. Platão. Timeu, 71e-72a.

43. Remeto o leitor ao que sobre isto escreveu Peter Pál Perlbart. Da clausura do fora ao fora da clausura. Loucura e desrazão (1989), pp. 21-32.

44. Cf. Junito Brandão. Dicionário mítico-etimológico (1991), tomo II, p. 287.

45. Idem, ibidem. 


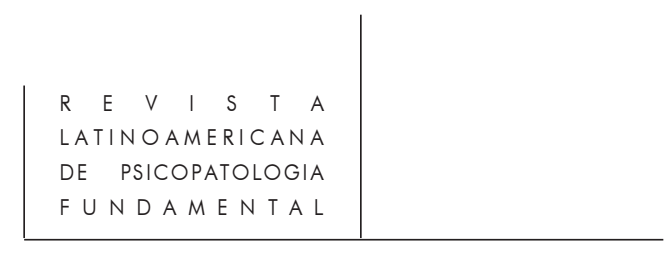

festas e rituais dionisíacos. Nas Bachantes, Eurípedes faz uma descrição minuciosa e impressionante desses rituais e das mulheres inspiradas por Dionísio. Na Grécia Antiga, a importância de Dionísio era tão grande quanto a de Apolo. Se este oferecia segurança ao desamparo daqueles que eram esmagados pelo medo dos deuses numa cultura dominada pelo sentimento de culpa, Dionísio garantia o sentimento de liberdade. Ele era o deus da alegria e de uma alegria que era acessível a todos. Dionísio era um deus do povo. O delírio ritualístico era uma oportunidade oferecida a todos de se libertarem, por momentos, da dureza da vida. Como observa Dodds, no seu magnífico livro Os Gregos e o Irracional, Dionísio era o mestre das ilusões mágicas. O objetivo de seu culto era possibilitar que o povo que dele participasse saísse de si e se livrasse, por algum tempo, do peso de suas calamidades ${ }^{46} \mathrm{Em}$ todas as modalidades dos rituais dionisíacos "há uma valorização da embriaguês dos sentidos, aspiração a uma beatitude do êxtase, um gosto pelo excesso. O enlevo dionisíaco não é só, porém, exaltação e júbilo. É inquietante, e na sua revulsão libera forças obscuras que o senso de equilíbrio grego reputava como terríveis" ${ }^{47}$. Por isso mesmo, poder-se-ia perguntar se os rituais purificatórios a que alude Platão, no Fedro,

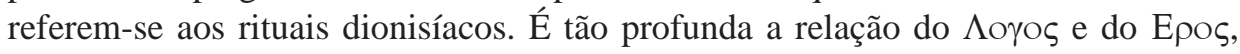
no Fedro, que dificilmente se concebe a possibilidade de, nele, ter lugar para o ritual dionisíaco, onde predominava o reinado absoluto do irracional. ${ }^{48}$

Provavelmente, Platão se refere aos cultos catárticos da época clássica, entre os quais se destacaram a catarse musical praticada pelos pitagóricos no século IV e os rituais coribânticos do século V. Nesses rituais catárticos, curavam-se as doenças psíquicas. Platão, nas Leis, fala de medos e ansiedades curados nesses rituais. O importante era saber qual o deus responsável pelo mal que se pretendia curar. Se o culto fosse dirigido a um outro deus, seu efeito era comprometido. Nestes casos, o prognóstico e o diagnóstico eram indispensáveis para o bom êxito da terapia.

O delírio poético

O terceiro delírio divino é o da inspiração poética que os favorecidos das Musas recebiam como um dom divino. Ninguém o exprimiu melhor do que Píndaro quando

46. Cf. E. R. Dodds. Os gregos e o irracional (1984).

47. P. P. Pelbart. Da clausura do fora ao fora da clausura. Loucura e desrazão (1989), p. 36.

48. Eis o que a respeito escreve Antonio Gomez Robledo no seu magistral estudo sobre os seis grandes temas da Filosofia de Platão: "Ninguna de las cuatro especies de mania descrita en el Fedro: profética, catártica, poética y retórica, lleva consigo la abolición de la inteligencia. (...) Nada tiene que hacer aqui Dionisios, el dios rival del divino Musageta, y por algo Platón se cuida bien de poner el delirio báquico, éste sí del todo irracional, entre las formas de delirio cuyos efectos han sido origen de grandes bienes para los hombres e para las ciudades. Cf. Antonio Gomes Robledo. Platón. Las seis grandes temas de su Filosofia (1993), pp. 427-428. 


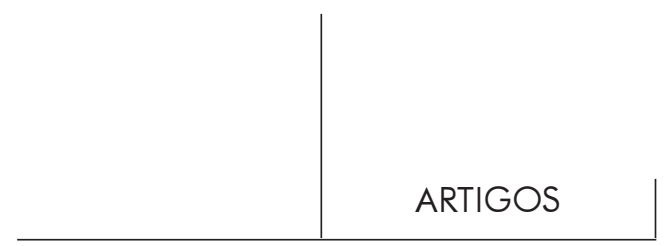

disse: "Dá-me, ó Musa, um oráculo e eu serei teu intérprete" 49 . Não há técnica nem arte capaz de substituir esta $\mu \alpha v \imath \alpha$ divina, que as Musas transmitem aos seus eleitos. Para ser poeta não basta saber escrever versos. "Aquele", escreve Platão, "que sem o delírio das Musas chegar às portas da Poesia, pensando que um conhecimento técnico basta para fazer dele um poeta, este será um poeta menor" ${ }^{50}$.

O delírio amoroso

E, finalmente, chegamos ao delírio amoroso, que aqui mais nos interessa. Platão termina identificando-o com o amor do filósofo pela verdade. E aqui está a grande novidade do Fedro. É no delírio amoroso do filósofo em que melhor aparece as duas estruturas fundamentais da alma: a noética e a erótica. E para apresentar esta estrutura erótica da alma, Platão, mais uma vez, recorre à linguagem do mito. E o mito escolhido foi o das carruagens aladas e de sua grande cavalgada pelas estradas dos céus. No que se refere à cavalgada, a linguagem é verdadeira mítica, mas o "carro alado" é uma alegoria, pois sua imagem corresponde ao que verdadeiramente Platão pensa sobre a alma humana.

Estrutura mítica da alma

Partindo da certeza de que "só os deuses seriam capazes de dizer o que verdadeiramente é a alma humana" 51 , Platão apela para a linguagem do mito. Ou seja, o discurso humano não pode dizer o que é a alma humana, pode dizer apenas ao que ela se assemelha. E a que ela se assemelha? Responde Platão:

... a alma pode ser comparada a uma força natural e ativa que unisse um carro puxado por uma parelha alada e conduzido por um cocheiro. Os cavalos e os cocheiros das almas divinas são bons e de boa raça, mas os dos outros seres são mestiços. O cocheiro, que nos governa, rege uma parelha na qual um dos cavalos é belo e bom, de boa raça, enquanto o outro é de má raça e de natureza contrária. Assim, conduzir nosso carro é ofício difícil e penoso. ${ }^{52}$

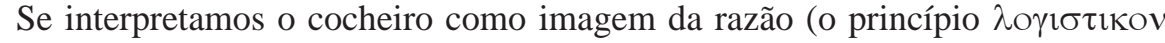
que dirige a alma) e os cavalos dócil e rebelde como imagens, respectivamente, do princípio $\theta u \mu \imath \mathrm{v}$ dócil à razão e do princípio $\varepsilon \pi \imath \theta v \mu \eta \tau \kappa o v$ insubordinado às ordens da razão, facilmente se compreende que o mito traduz e oculta, na linguagem dos símbolos, a doutrina tripartida da alma exposta na República.

49. Píndaro. Frag. 150. Citado por Dodds. Os gregos e o irracional (1984).

50. Platão. Fedro, 245e.

51. Idem, ibidem, 246a.

52. Platão. Fedro, 245e-246a. 


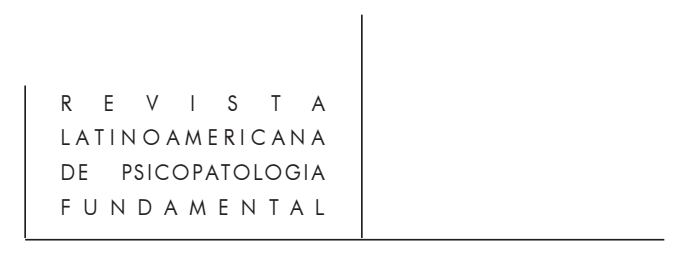

Léon Robin, no seu célebre estudo sobre a teoria platônica do amor, propõe uma interpretação do mito do carro puxado pela parelha alada e dirigida pelo cocheiro, uma interpretação que me parece muito interessante. Ele o articula ao mito do Timeu, quando Platão nos fala do Mesmo e do Outro. O Mesmo seria a expressão mais adequada da Idéia, porquanto as Idéias representam a essência indivisível, sempre idêntica a si mesma. Elas fundamentam o ser na metafísica de Platão. Já o Outro aparece como aquilo que é o princípio do devir, do não-ser e da irracionalidade. Por conseguinte, o princípio da contrariedade e da desordem.

Aplicando isto ao Fedro, Robin vê, no cocheiro, a inteligência que, enquanto vous, é o piloto da alma. Ela é uma expressão do Mesmo e sua pátria é o Mundo das Idéias. Os cavalos representam o Outro, enquanto princípio da multiplicidade, da divergência e da contrariedade. Nos cavalos dos deuses, o Mesmo predomina sobre o Outro. Mas nos cavalos dos mortais, ora pode predominar o mesmo, ora o Outro. E é precisamente quando isto acontece que as almas perdem as suas asas e caem na prisão dos corpos.

Isto fica mais claro quando lembramos como Platão descreve a grande cavalgada dos carros alados pelas estradas dos céus. Desta grande carreata participam as almas, tanto dos deuses quanto as dos mortais. Os carros dos deuses dirigem-se

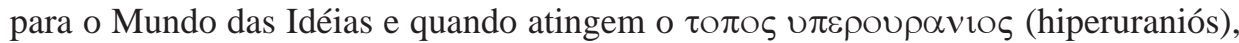
ou seja, o lugar supercelestial, elas se regalam com a contemplação das verdades absolutas. Os carros alados das almas dos mortais que as seguem, na ânsia de participarem também desta contemplação bem-aventurada, por falta da habilidade dos cocheiros, roçam e estragam suas asas umas nas outras, o que provoca a queda das almas nos corpos.

Antonio Robledo opina que, neste contexto, a queda das almas, no mito do Fedro, lembra a queda dos anjos rebeldes do mito bíblico. Não é porque se prende aos prazeres sensíveis que a alma perde as suas asas, é por tê-las perdido que ela agora se deleita nos prazeres sensíveis, até que a vista das coisas belas desperte nelas a lembrança de suas origens e o amor da filosofia faça de novo crescer as suas asas. ${ }^{53}$

Depois de um período mais ou menos longo, as almas podem reaver suas asas. Isto acontece quando, durante o período em que se encontram prisioneiras do corpo, elas contemplam as coisas belas e cultivam o amor filosófico. É o amor filosófico que faz crescer as asas das almas. Elas, então, só pensam em se elevar até o divino.

Mas deixemos o "lugar supercelestial" onde, para Platão, se encontra a morada definitiva da alma humana e perguntemo-nos o que, sobre o desejo, nos ensina o filósofo de Estagira, Aristóteles, que recolocou, na terra, a filosofia que Platão colocara nos céus. 


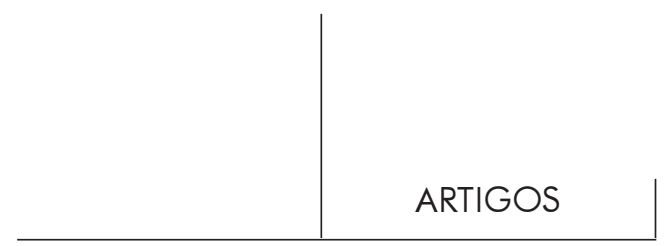

4. O desejo na filosofia de Aristóteles

Antes de deixarmos a Grécia Clássica, vamos resumir o essencial da sistematização teórica que Aristóteles deu à noção de desejo no contexto de sua doutrina sobre a alma humana. $\mathrm{Na}$ abordagem aristotélica, o desejo tem o nome genérico de $0 \rho \varepsilon \xi 1 \varsigma^{54} \mathrm{e}$, sob ele, foram reunidas as principais formas específicas do desejo, vale dizer, o desejo-cobiça $(\varepsilon \pi \imath \theta u \mu \imath \alpha)$, o desejo-arrebatamento $(\theta v \mu \circ \varsigma)$ e o

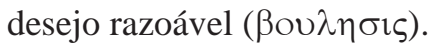

Na contribuição que Aristóteles deu para o estudo do desejo, podemos ressaltar três itens mais importantes: a) primeiramente, ele retomou o que já tinha sido dito pelos filósofos pré-socráticos e pelos poetas épicos sobre o thymós; b) depois, ele repensou o lugar e a função do desejo a partir do "modelo tripartido" da alma humana apresentado na psicologia de Platão; c) finalmente, no contexto de sua metafísica hilemorfista, ele colocou o que se poderia dizer os fundamentos de uma metafísica do desejo, destacando o seu papel na dinâmica do ato humano. Pode-se, portanto, dizer que, com Aristóteles, o desejo encontrou um novo estatuto e uma fundamentação verdadeiramente metafísica.

$\mathrm{O}$ trabalho de fundamentação metafísica do desejo, no entanto, representa o término de uma longa trajetória que atravessa toda a evolução do pensamento filosófico de Aristóteles, o qual conheceu, ao menos, três fases essenciais ${ }^{55}$ : a fase platônica, quando ele, ensinando na Academia, ainda estava sob a influência direta do mestre Platão; a fase que Ross chama de "biologista" 56 , e que outros preferem chamar de "instrumentalista, ou seja, a fase intermediária entre a Academia e o Liceu;

54. Inicialmente o termo o $\rho \varepsilon \xi 1 \varsigma$ designava exclusivamente os desejos irracionais. Era o $\mu \eta$ (tendência, impulso) o termo utilizado por Aristóteles para designar genericamente tanto o

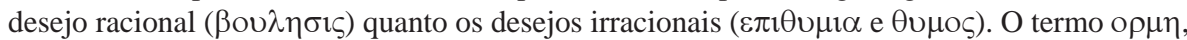
porém, tinha um sentido muito amplo e designava tanto as tendências e inclinações existentes no mundo animal, quanto as do mundo inanimado. Estas tendências eram também aplicadas à alma humana. Depois o termo o $\rho \varepsilon \xi 1 \varsigma$ tornou-se, para Aristóteles, o termo genérico para designar o desejo, abraçando tanto o desejo racional quanto os desejos irracionais. Cf. a este respeito R. A. Gauthier e J.Y. Jolif. L'éthique à Nicomaque (1959), tome II, p. 95.

55. Esta maneira de ver a evolução do pensamento de Aristóteles deve muito ao extraordinário trabalho de Werner Jaëger sobre Aristóteles, aparecido, primeiramente, em 1923 e reeditado, depois, em Berlin em 1955. Como de uma fonte deste trabalho surgiram muitos estudos excelentes sobre a filosofia de Aristóteles e, entre eles, o magnífico livro de F. Nuyens sobre a evolução da psicologia de Aristóteles. É a este trabalho de Nuyens que devemos a divisão das fases idealista ou platônica, instrumentalista ou mecanicista e, finalmente, hilemorfista. Cf. F. Nuyens. L'évolution de la psychologie d'Aristote (1948).

56. Cf. D. Ross. Aristotle's Parva Naturalia. Oxford, 1955, p. 12. Citado por R.A. Gauthier. La morale d'Aristote. Paris: PUF, 1958, p. 9. 
e, finalmente, a fase hilemorfista, na qual Aristóteles desenvolveu sua maneira própria de conceber o ser e, a partir daí, o homem (antropologia) e o modo do homem se comportar na cidade (ética e política).

Vamos acompanhar a trajetória da evolução do pensamento aristotélico, sublinhando o que, em cada uma dessas fases, Aristóteles escreve sobre o desejo e suas metamorfoses. Essencialmente, as três fases correspondem aos três itens supraindicados. Comecemos com a fase platônica.

Enquanto esteve na Academia, Aristóteles, como era de esperar, sofreu uma influência muito significativa de seu mestre Platão. Ao menos duas das idéias fundamentais de Platão o impressionaram bastante, ou seja, a idéia da alma exilada no corpo e, depois, a convicção de que esta alma só almeja retornar para o mundo das Idéias, que é sua verdadeira pátria. Não é de admirar que, durante esta fase platônica, a problemática do desejo só interessasse a Aristóteles, à medida que um "desejo ardente" ( $\pi \rho \circ \theta v \mu \imath \alpha)$, semelhante àquele que alimentava o $\theta u \mu \circ \zeta$ homérico e platônico, traduzia a necessidade da alma evadir-se do corpo e voltar para o mundo das realidades originárias.

É o que se pode constatar numa leitura do Proteptico, o primeiro tratado moral de Aristóteles, escrito ainda sob a influência de Platão. Como quer que seja, os especialistas observam que, mesmo então, já se pode notar a preferência de Aristóteles por um vocabulário relativo ao desejo, no qual os termos usados por Platão - tais

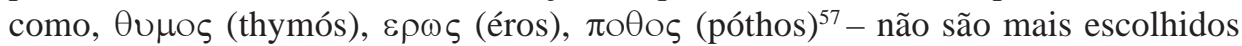
nem ressaltados, por causa de sua dimensão poética e mítica. ${ }^{58}$ Nos Tópicos, embora ainda continuasse sob a influência do mestre Platão, Aristóteles já demonstrava uma certa originalidade, particularmente quando questionava algumas das teses fundamentais da filosofia platônica, tais como a imortalidade da alma e a desvalorização do corpo. No entanto, Aristóteles ainda aceitava a visão tripartida da

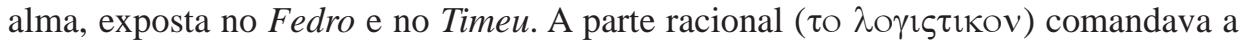

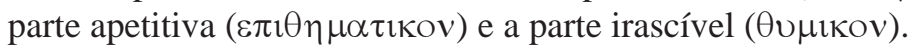

Nada melhor, para ilustrar a passagem da fase platônica para a fase instrumentalista ou biologista, do que a análise que Aristóteles deixou sobre o $\theta v \mu \circ \varsigma$ (thymós) nas diversas etapas da evolução de seu pensamento filosófico. ${ }^{59}$ Já vimos

57. O termo $\pi \mathrm{o} \theta \mathrm{o} \varsigma$ (póthos) era freqüentemente empregado pelos poetas para designar o amor ardente, mas vivido de uma forma lancinante. $\mathrm{O}$ desejo de algo que se quer muito, mas que não está presente e sim ausente. Qualquer coisa da ordem da saudade. Vejam-se as referências desta acepção do desejo em Gauthier e Jolif, L'éthique à Nicomaque (1959), tome II, p. 134.

58. Cf. o interessante capítulo "L'élan vers le vrai" do livro de Jean Frère: Les grecs et le désir de l'être (1981), pp. 293-298.

59. O leitor encontrará também no livro citado de Jean Frère uma magistral análise do thymós nos diversos momentos da trajetória da evolução do pensamento filosófico de Aristóteles. 


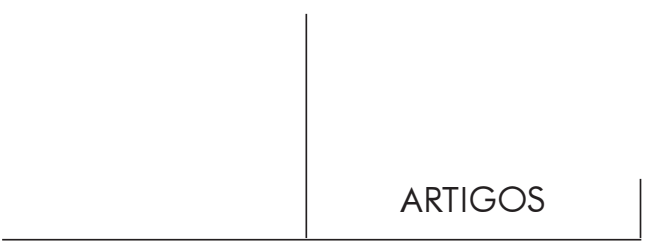

como, desde Homero, esta palavra representa uma das mais constantes e expressivas metamorfoses do desejo. O $\theta u \mu$ os (thymós), enquanto desejo ardente, está no centro das doutrinas que os filósofos pré-socráticos elaboraram sobre a alma humana. Aristóteles não é uma exceção. No entanto, ele operou uma grande modificação na conceitualização do $\theta u \mu$ os. No lugar de fazer dele, como fizera Platão, uma parte

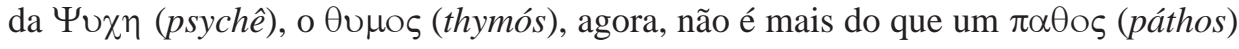
da parte desejante da alma.

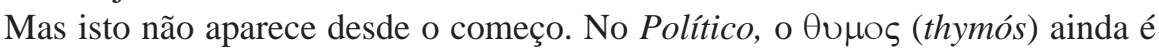

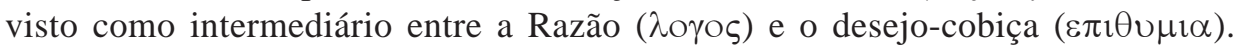
Somente quando questiona e abandona a visão platônica tripartida da alma, Aristóteles deixa de olhar o $\theta u \mu \circ$ (thymós) como intermediário entre Razão e Desejo, e o considera seja como um "arrebatamento" apaixonado, seja como um transbordamento colérico da parte desejante da alma humana. Noutras palavras, em vez de ser considerado como uma das partes estruturantes da $\Psi v \chi \eta$ (psychê), o $\theta v \mu \circ \varsigma$ (thymós) passa a ser olhado como um $\pi \alpha \theta \eta \mu \alpha$ (pathema) da alma. E seu estado é caracterizado por uma "impulsividade", que corresponde ao sentimento da cólera

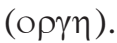

Esta articulação entre $\theta u \mu \circ$ e o $ү \eta$ (cólera) aparece, por exemplo, nas Éticas a Eudemo e a Nicômaco (que foram escritas na fase instrumentalista). A opүๆ traduz, de preferência, as manifestações exteriores do arrebatamento ou da cólera, e o $\theta u \mu o \varsigma$ a interioridade da alma que se encontra em estado de arrebatamento ou de cólera. $^{60}$

Todavia, esta nova acepção do $\theta u \mu \circ \varsigma$ aristotélico só pôde ser bem compreendida, quando foi situada no contexto da nova visão da alma que Aristóteles começou a elaborar nesta fase instrumentalista. A partir daí, a alma passou a ser estuda-

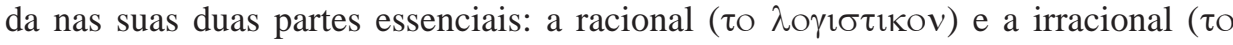
$\alpha \lambda \circ \gamma \circ \mathrm{v})$.

A parte desejante da alma

$\mathrm{Na}$ parte irracional temos, primeiramente, um lado que é pura e simplesmente

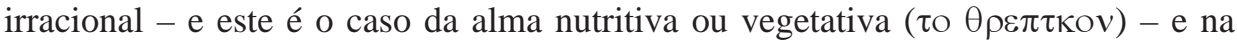
parte racional um lado que é puramente racional que é a alma intelectiva ( $\tau$ o

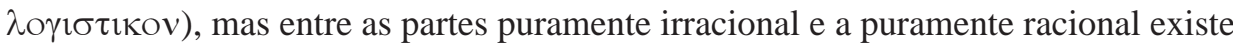
uma parte que é meio-irracional e meio-racional. Este lado, que se apresenta assim como um conceito-limite entre o racional e o irracional, e que Aristóteles chama de

60. Remeto o leitor para maiores esclarecimentos ao livro de Jean Frère. Les grecs et le désir de l'être (1981), p. 311. 


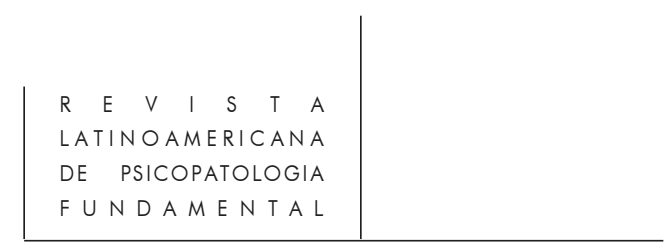

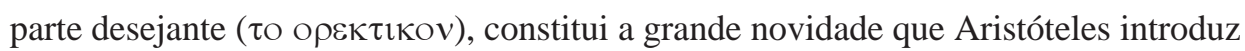
na sua tentativa de sistematizar teoricamente o desejo. ${ }^{61}$

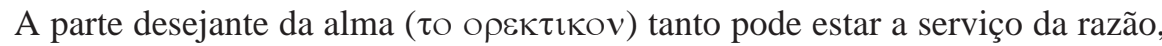
quanto pode a ela se opor. Enquanto está a serviço da razão, Aristóteles a chama de

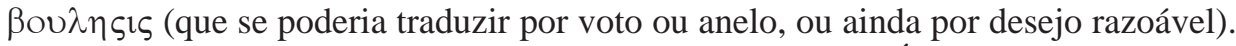
Mas enquanto se opõe à razão, ela se chama $\varepsilon \pi \imath \theta u \mu \imath \alpha$. É o desejo-cobiça que aprisiona a alma aos prazeres sensíveis. Todavia, a parte desejante nem sempre vai de encontro à razão. Algumas vezes, ela pode ir ao encontro da razão e ouvir-lhe a voz. Quando isto acontece temos, então, um $\theta v \mu \circ$ ou um desejo-arrebatamento esclarecido. Quando, porém, a parte desejante vai de encontro à razão, tanto o desejo$\varepsilon \pi \imath \theta u \mu \iota \alpha$ quanto o desejo- $\theta$ vos levam o sujeito a perder o controle de si, o que o animaliza ou infantiliza. ${ }^{62}$ Por mais que se ligue ao racional, a parte desejante que se manifesta como $\beta$ ov $\lambda \eta \iota \varsigma$ continua sendo desejo. Ela não deve ser considerada como

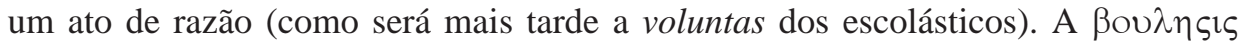
aristotélica é essencialmente desejo. Um desejo, porém, a serviço da razão.

À medida que Aristóteles deixa a fase instrumentalista pela hilemorfista, ele também modifica sua maneira de conceber o $\theta u \mu \circ$, o qual, em vez de ser visto apenas na perspectiva da alma, é também olhado em relação ao composto corpo e alma. Neste novo contexto, aparece claramente por que os jovens são mais freqüentemente dominados pelo $\theta v \mu$ os do que os velhos. Mas, entre o fácil arrebatamento dos jovens e a $\alpha \theta v \mu \imath \alpha$ dos velhos, o meio-termo ideal ( $\mu \varepsilon \tau \alpha \zeta v)$ é o $\theta$ uros do homem amadurecido.

\section{O desejo na dinâmica do ato humano}

À medida que a $0 \rho \varepsilon \xi 1 \zeta$ adquire um novo estatuto na evolução do pensamento aristotélico, o desejo deixa de ser situado preferencialmente na parte irracional da alma e tem seu lugar na parte racional. Não que Aristóteles tenha feito dele, como já foi observado, um ato de razão, mas nas suas manifestações mais altas, o desejo tem um lugar de destaque na psicologia e na ética de Aristóteles, como uma força que trabalha juntamente com a razão.

61. Veja-se o esquema gráfico que propõem Gauthier e Jolif no seu comentário à Ética de Nicômaco (L'éthique à Nicomaque [1981], tome II, p. 97).

\section{Alma}

Irracional

$$
\text { Desejante }
$$

Racional

Vegetativa

(puramente irracional) (meio-irracional e meio-racional)

Racional

(puramente racional)

62. CF. Aristóteles. Ética a Eudemo, 1229a, 22-38. 
Nada ilustra melhor a importância que Aristóteles atribui ao desejo do que mostrar o seu lugar e a sua função na dinâmica do ato humano. Nela, a ordem do desejo tem um papel análogo à ordem do intelecto. E como se trata da ordem do agir e

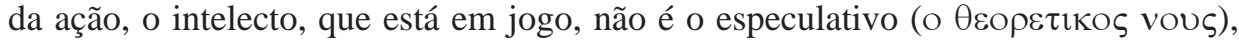
mas o intelecto prático (o $\pi \rho \alpha \kappa \tau \imath \kappa o \zeta ~ v o u \varsigma$ ) que raciocina em vista de um fim. E é precisamente por causa deste fim, que o intelecto não se move sem o desejo. $\mathrm{O}$ objeto do desejo - o desejável - é o motor primeiro do intelecto prático. O desejo está na base de toda ação verdadeiramente humana. Sem desejo, o homem nada faz.

Sem dúvida, na origem do ato humano, Aristóteles coloca, em primeiro lugar, o pensamento ou o intelecto. Pois, o homem é essencialmente intelecto. É essencialmente pensamento. Além do mais, segundo Aristóteles, não se deseja senão aquilo que se julga ser um bem. Desejamos algo quando este algo nos parece bom, e não ele nos parece bom porque o desejamos. ${ }^{63} \mathrm{Na}$ origem da ação está, portanto,

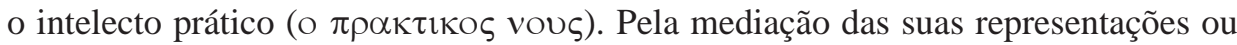
das suas imagens ( $\varphi \propto \nu \tau \alpha \sigma \iota \alpha)$, o intelecto faz aparecer, na alma, a idéia ou a forma de um objeto para o qual se dirige sua ação. O objeto, assim representado, aparece ao sujeito da ação como um bem ( $(\alpha \imath v o \mu \varepsilon v o v ~ \alpha \gamma \alpha \theta \circ v)$. Mas para que ele possa partir para a ordem da ação, se faz necessário que entre em cena uma outra coisa,

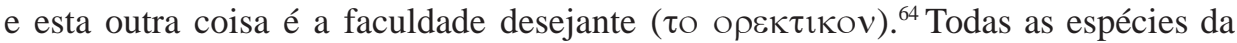
o $\varepsilon \xi 1 \varsigma$ ( $\varepsilon \pi \imath \theta u \mu 1 \alpha$ e $\theta u \mu \circ \varsigma)$ podem determinar, ou ter alguma influência, sobre a

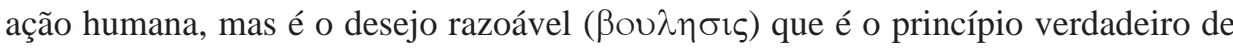
uma autêntica ação humana, como, por exemplo, da ação virtuosa.

Uma vez que o desejo inicia o processo, este se desenvolve espontaneamente. O intelecto prático começa, então, a deliberar, ou seja, procura os meios adequados para a consecução do fim desejado pelo sujeito. Tem lugar, então, um juízo de valor, no qual são articulados o desejo que visa o fim e o meio adequado para sua consecução, meio este que o sujeito passa também a desejar. Surge, assim, a decisão,

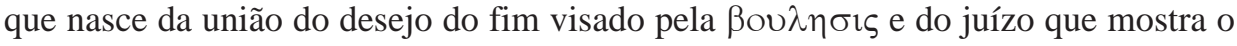
meio adequado para atingir o fim (a $\pi \rho \circ \alpha \imath \rho \varepsilon \sigma \iota \varsigma)$.

63. "Desejamos alguma coisa porque ela nos parece boa e não o contrário: ela nos parece boa porque a desejamos, pois o princípio é o pensamento". Cf. Aristóteles. Metafísica, livro $\Lambda 7$. 1072a 29-30. Ed. Tricot (1953), pp. 676-678.

64. Cf. Discutindo o problema das partes da alma, Aristóteles afasta tanto a divisão tripartida de Platão quanto a de Xenócrates que se contentava em dividir a alma em duas partes: uma racional e outra irracional. Para Aristóteles a dificuldade desta divisão bipartida é que nela não se sabe onde colocar a parte sensitiva, imaginativa e, sobretudo, desejante, a qual tanto pela sua forma quanto pela sua potência parece ser diferente de todas as precedentes, e que, no entanto, sem absurdo não pode ser separada das outras partes: porque é na parte racional que o desejo refletido nasce e, na parte irracional, o apetite e o impulso. Numa divisão tripartida, o desejo figuraria nas três partes. Cf. Aristote. De l'âme. III, 9432 b. 5 . 


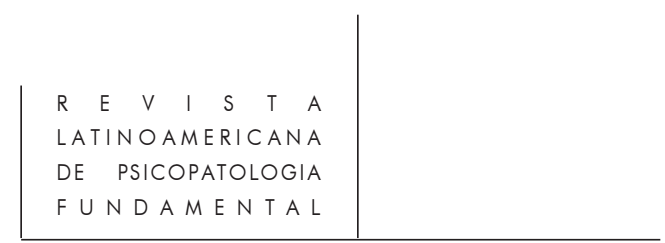

Deliberação e decisão

O conceito de decisão é, indiscutivelmente, uma das manifestações mais altas da $0 \rho \varepsilon \xi 1 \varsigma$ aristotélica, porquanto nela temos, ao mesmo tempo, um intelecto que deseja e um desejo que raciocina. Deve-se daí concluir que a decisão é de natureza desejante antes que intelectiva? Por mais impregnada de desejo que esteja, a decisão continua, para Aristóteles, um ato do intelecto. Para ele, é o intelecto que decide. Mas não se deve esquecer que este intelecto é o intelecto prático o qual, para poder mover-se, deve primeiramente ser impulsionado pelo desejo. Como observam Gauthier e Jolif, a decisão está diante do desejo e da razão numa situação análoga à da conclusão diante das premissas de um silogismo. Da mesma forma que a conclusão de um silogismo não é uma outra premissa distinta das premissas maior e menor que formam o silogismo, a decisão também não é outra coisa senão o ponto de junção ou de fusão do desejo e da razão.$^{65} \mathrm{~A}$ decisão é o juízo que encerra a deliberação, mas este juízo é impulsionado pelo desejo que o penetra e dinamiza. Ora, uma razão, movida pelo desejo, pode ser considerada também como um desejo esclarecido pela razão.

A decisão volta-se para os meios para melhor visar o fim, pois do contrário o desejo do fim seria ineficaz. Nem causaria nenhum engajamento. O desejo só se transforma em decisão quando, após a deliberação, o sujeito julga que o meio que está a seu alcance é eficaz para alcançar o fim desejado. O objeto do desejo é, ao mesmo tempo, enunciado pela razão e perseguido pelo desejo. Novamente, Aristóteles articula, pela mediação do objeto da ação, a ordem do pensamento e a ordem do desejo.

\section{Para uma metafísica do desejo}

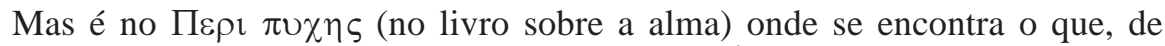
mais profundo, escreveu Aristóteles sobre o desejo. À luz da doutrina metafísica do ato e da potência, o Estagirita, a partir do que disse sobre o desejo do ser, vai tentar perscrutar algo sobre o "ser do desejo". Esta metafísica do desejo está correlacionada com o que já foi dito sobre o movimento e o princípio do movimento. ${ }^{66}$

65. Cf. R.A., Y.L. Jolif. L'éthique à Nicomaque (1958), tome II, p. 212.

66. Sobre o fundamento metafísico do desejo remeto o leitor ao que escreve Jean Frère no capítulo "La puissance et l'acte, ou le fondement du désir" no livro, já tantas vezes citado, Les grecs et le désir de l'être (1981), pp. 405-412. Neste livro, minha pesquisa encontrou uma de suas fontes mais ricas e valiosas. 


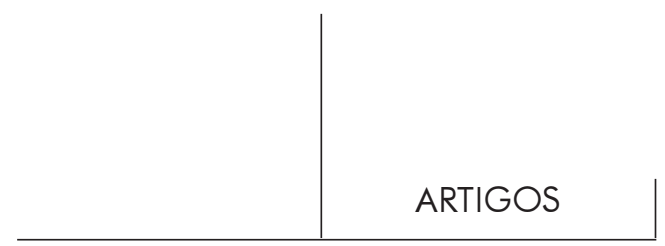

Já sabemos que, para Aristóteles, o desejo é o princípio do movimento. Enquanto tal, ele também está sujeito à doutrina do ato e da potência. Metafisicamente

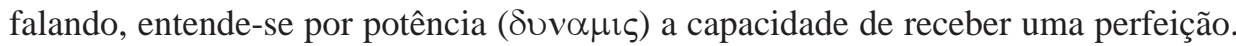
A potência, portanto, é o segredo das possibilidades existenciais que o ser humano, e todo ser em geral, possuem. Tudo aquilo que, de um modo ou de outro, pode ser atualizado no ato de existir, está no estado de potência. Entre o poder-ser e o ser existe um movimento de passagem e de mudança. A $\delta v v \propto \mu \iota \varsigma$, diz Aristóteles, designa "o princípio do movimento ou da mudança em um outro ser, ou no mesmo ser, enquanto ele é outro" ${ }^{17}$. O que vale dizer que ela é uma força ativa, ou uma capacidade de mudança. Mas ela é também uma força passiva, à medida que pode ser modificada. Em ambos os casos, ela implica a idéia de mudança.

Pois bem, à luz da noção aristotélica de "potência", o ser revela sua face inacabada, pois está sempre atualizando suas possibilidades existenciais. Pela arte do escultor, a pedra bruta tem possibilidade de se tornar uma estátua. A forma da estátua que é inserida na sua matéria de pedra atualiza esta possibilidade, de que era privada enquanto era simples pedra. Mas para que a forma seja atualizada na matéria, necessário se faz, primeiro, que ela seja desejada pelo artista, pois é o desejo a causa do movimento que leva o artista a realizar sua obra.

Dinamizada pelo desejo, a potência não apenas revela a face inacabada do ser, ela revela também o impulso que leva o ser a buscar seu aperfeiçoamento. Para caracterizar esse impulso, os gregos utilizavam a palavra o $\mu \eta$ que, antes de o $\rho \xi \xi 1 \varsigma$ era o nome que o próprio Aristóteles usava para exprimir, de um modo genérico, todas as modalidades de desejo. Pois bem, é este aperfeiçoamento que a potência encontra no ato. Todo impulso para o aperfeiçoamento é, em última análise, procura de um fim e de uma perfeição que a potência encontra quando é atualizada pela perfeição do ato. Este ato que está no fim do movimento é, ao mesmo tempo, o seu início. O fim que é último na ordem da execução é o primeiro na ordem intenção. Pois bem, é neste fim último, que é primeiro, que se esconde o fundamento metafísico do desejo.

\section{O Supremo inteligivel e o Supremo desejável}

No capítulo 7 do livro $\Lambda$ da Metafísica, a metafísica do desejo, tal como Aristóteles a elaborou, encontra seu ápice e seu aperfeiçoamento último. Neste capítulo, Aristóteles escreveu o que entende sobre a divindade e tentou definir-lhe a natureza. E como era de se esperar, ele a definiu como o "Motor Imóvel", causa primeira e fim último de tudo o que se move no mundo. Mas este Princípio primeiro 
é também o "Ato puro" e o "Supremo desejável", causa originária ( $\alpha \rho \chi \eta)$ e fim $(\tau \varepsilon \lambda \circ \varsigma)$ de tudo o que existe.

Como fizera na análise da dinâmica do ato humano, Aristóteles articula também, no ápice de sua Metafísica, a ordem do inteligível e a ordem do desejável. Da mesma forma que o pensamento prático, que é causa do movimento, encontra o princípio de seu movimento no desejável, do mesmo modo o "Inteligível supremo" e o "Supremo desejável", de novo, se articulam e, diz Aristóteles, que "tomados em seu grau supremo, eles se identificam" ${ }^{\circ 8}$.

Todos os seres tendem para este princípio primeiro que é, ao mesmo tempo, o fim último de tudo o que existe, mas não o fazem do mesmo modo. Enquanto os seres inanimados e irracionais são movidos metafisicamente pela força instintiva da o $\mu \eta$, os seres humanos não só "tendem para", mas verdadeiramente "desejam"

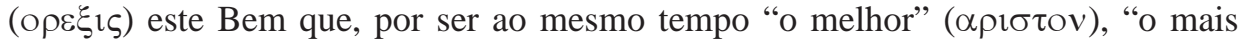

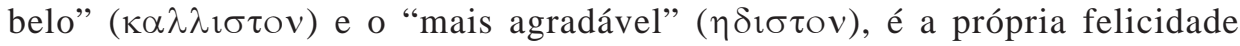

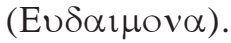

Aqui estão, muito resumidas, as principais idéias que estruturam a sistematização teórica dos grandes pensadores da Grécia Clássica sobre o desejo. Resta-nos, ainda, mais uma etapa nesta caminhada que traçamos para estudar o desejo na Grécia Antiga. Vamos perguntar o que, sobre o desejo, se disse no Jardim de Epicuro e no Pórtico antigo de Stoa. Este será o roteiro da próxima caminhada.

\section{Referências Bibliográficas}

ARAúJo JR. Anastácio Borges de. Platão e Freud: duas metáforas da alma humana. Tese de Mestrado no Departamento de Filosofia da Universidade Federal de Pernambuco. Recife, março de 1999.

Aristote. La Métaphysique. Nouvelle Édition completemente refondue avec commentaire par J. Tricot. Paris: Librairie Philosophique J. Vrin, 1963.

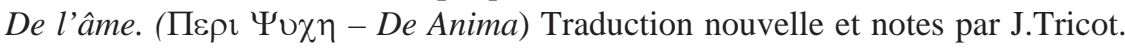
Paris: Librairie Philosophique J. Vrin, 1947.

Brandão, Juanito. Dicionário mítico-etimológico. Volumes I-II. Petrópolis: Vozes, 1992.

DodDs, E. R. Os gregos e o irracional. Trad. de Leonor Santos B. de Carvalho. Lisboa: Gradiva, 1988.

Frère, Jean. Les grecs et le désir de l'être. Des Préplatoniciens à Aristote. Paris: Les Belles Lettres, 1981.

Freud, S. "Formulierungen über die zwei Prinzipien des psychischen Geschehens" (1911)

Studienausgabe. Band III, 13-24. 


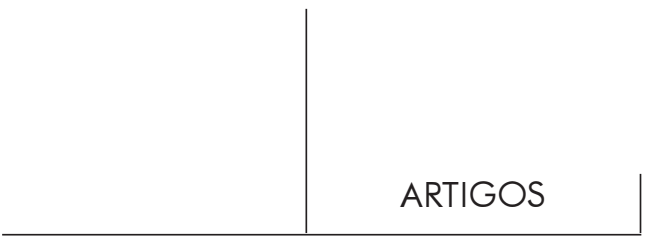

Gauthier, René Antoine e Jolif, Jean Yves. L'Éthique Nicomaque. Tome II. Commentaire. Deuxième Partie. Livres VI-X. Louvain/Paris: Publications Universitaires de Louvain/ Éditions Béatrice/Nauwelaerts, 1959.

Gauthier, René A. La morale d'Aristote. Paris: Presses Universitaires de France, 1958.

Grube, G.M.A. El pensamiento de Platón. Trad. espanhola de Tomás Cavo Matinez. Madrid: Editorial Gredos, 1987.

Guthrie, W.K.C. Les grecs et leurs Dieux. Traduit de l'anglais par S.M. Guillemin. Paris: Payot, 1956.

JäGER, Werner. PAIDEIA. Los ideales de la cultura griega. 3 Volumes. Trad. española de Joaquin Xirau. Mexico: Fondo de Cultura Económica, 1953.

MckeOn, Richard. The Basic Works of Aristotle. New York: Random House, 1941.

Pelbart, Peter Pál. Da clausura do fora ao fora da clausura. Loucura e desrazão. São Paulo: Brasiliense, 1989.

Platon. Oeuvres complètes. Tomes I - II. Col. La Pléiade. Tradução e notas de Léon Robin. Paris: Gallimard, 1957.

Oeuvres complètes. Tome IV - 2 ${ }^{\mathrm{e}}$ Partie. "Le Banquet”. Texte établi et traduit par Léon Robin. Paris: Les Belles Lettres, 1962.

O banquete ou do amor. Introdução, tradução e notas do Prof. J. Cavalcante de Souza. 4a edição. São Paulo: Difel, 1986.

Diálogos. Eutífron ou da religiosidade. Apologia de Sócrates. Críton ou do dever e Fédon ou da alma. Tradução de Márcio Pugliesi e Edson Bini. São Paulo: Hemus, s/d.

Ramnoux, Clémence. Héraclite ou l'homme entre les choses et les mots. Paris: Les Belles Lettres, 1959.

Reale, Giovanni. Historia da Filosofia Antiga. 5 volumes. Trad. de Henrique C. de Lima Vaz e Marcelo Perine. São Paulo: Companhia das Letras, 1994.

Robledo, Antônio Gomez. Platón. Los seis grandes temas de su filosofia. Mexico: Fondo de Cultura Económica/Universidad Nacional Autónoma de Mexico, 1993.

RochA, Zeferino. A morte de Sócrates. Uma mensagem para nosso tempo. Recife: Editora Universitária da UFPE, 1994.

"A questão da diferença e do sujeito no horizonte filosófico da crítica da racionalidade moderna”, in Síntese Nova Fase. Vol. 21, no 67 (1994), pp. 449-477.

RoHDE, Erwin. Psyché. Le culte de l'âme chez les grecs et leur coryance a l'immortalité. Édition française par Auguste Reymond. Paris: Payot, 1952.

VAn REeTh, Claude. "O banquete ou a ilusão amorosa. Leitura de Freud à luz do Banquete", in Kriterion (1977), nº 70, pp. 107-123.

VAZ, Henrique Cláudio de Lima. Antropologia filosófica (I-II). São Paulo: Loyola, 3ae ed., 1993.

"Eros e logos. Natureza e educação no Fedro platônico", in Verbum IX (1952), pp. 161-180.

"Amor e conhecimento. Sobre a ascensão dialética no "Banquete", in Revista Portuguesa de Filosofia. Tomo XII. Fasc. 3 (1956), pp. 225-242. 
"Platão revisitado. Ética e metafísica nas origens platônicas", in Síntese Nova Fase. Vol. 20, no 61 (1993), pp. 181-197.

Escritos filosóficos III - Filosofia e cultura. São Paulo: Loyola, 1997.

\section{Resumos}

El presente trabajo corresponde a la segunda parte de la investigación que estamos realizando sobre "El deseo en la Grecia Antigua" y tiene como objetivo mostrar las primeras sistematizaciones teóricas que los filósofos de la Grecia Clásica, de modo particular Sócrates, Platón y Aristóteles, hicieron sobre las manifestaciones del deseo elaboradas por los poetas épicos, líricos y trágicos y por los filósofos de la Grecia Arcaica. Destacamos, de modo especial, el "Eros" socrático y lo que Platon nos dice sobre "Eros" en El banquete y en Fedro. Finalmente intentamos resumir lo erssencial de la doctrina de Aristóteles sobre los fundamentos de una mertafisica del deseo.

Palavras llave: Deseo, dialectica, Eros, psyche, metafisica del deseo

Le présent travail est la deuxième partie d'une recherche sur "Le désir dans la Grèce Ancienne" et son but est la présentation des premières systématisations théoriques que les philosophes de la Grèce Classique, notamment Socrate, Platon et Aristote, ont donné aux manifestations du désir élaborées par les poètes épiques, liriques et tragiques et par les philosophes de la Grèce Archä̈que. Nous avons mis en relief l'Éros socratique et l'essentiel de ce que Platon a écrit sur Éros dans Le Banquet et dans le Phèdre. Finalement, nous avons essayé de résumer l'essentiel de la doctrine d'Aristote sur les fondements d'une métaphysique du désir.

Motes clés: Désir, dialectique, Eros, psiqué, métaphysique du désir

This paper represents the second part of a research project I am conducting on "Desire in Ancient Greece". It brings together the early theoretical considerations of Classical Greek philosophers, particularly those of Socrates, Plato and Aristotle, on manifestations of desire in the works of epic, lyric, and tragic poets and Archaic Greek philosophers. Special emphasis is given to the Socrate notion of Eros and to Plato's discussion of Eros in the dialogues Symposium and Phaedrus. Finally, I aim to summarize Aristotle's doctrine on the foundations of a metaphysics of desire.

Key words: Desire, dialectics, Eros, psyche, metaphysic of desire 